\title{
Quantified Expressions and Quantitative Clitics
}

\author{
Anna Cardinaletti and Giuliana Giusti \\ $\mathrm{Ca}^{\prime}$ Foscari University of Venice, Italy
}

1 Introduction

2 The structure of quantified expressions

2.1 Extended Standard Theory proposals

2.1.1 The Hidden Partitive Hypothesis

2.1.2 The Simple Noun Phrase Hypothesis

2.2 GB proposals

2.3 The functional structure of quantified expressions

2.3.1 The DP hypothesis

2.3.2 The QP hypothesis

2.3.3 The AP hypothesis

2.3.4 A unified hypothesis

2.4 Conclusions

3 Partitive phrases

3.1 The "genuine" partitive PP

3.2 The adjunct partitive PP

3.3 The "kind" PP

3.4 The non-distinctness requirement

3.5 Universal quantifiers and partitive PPs

4 The syntax of quantitative clitics

4.1 General properties

4.2 Quantitative clitics as $\mathrm{N}^{\prime}$

4.3 Quantitative clitics as maximal projections

4.4 The category of quantitative clitics

4.4.1 Quantitative clitics as PPs

4.4.2 Quantitative clitics as DPs 
4.4.3 Quantitative clitics as KIPs

4.4.4 Quantitative clitics as NPs

4.4.5 Quantitative clitics and English one

4.5 Quantitative er in Dutch

5 The empty quantitative phrase

6 Conclusions

\section{Introduction}

Quantitative clitics (often called partitive clitics) characterize a small number of the languages of Europe, notably Italian, French, and Catalan among Romance languages and Dutch among Germanic languages. They generally co-occur with an existential quantifier in argument or dislocated position. For this reason, the study of quantitative clitics must be set in a broader investigation of the quantified nominals with which they occur. Quantifiers and other quantity items (i.e., vocabulary items denoting quantity) can, however, appear in a wide range of constructions. This chapter focuses on constructions containing cardinals and existential quantifiers that appear with quantitative clitic pronouns, namely the equivalent of many, few, some. Universal (all, both) and distributive (every, each) quantifiers will be treated when relevant to the discussion; other quantity items like quantity nouns (e.g., lot in a lot of people), measure nouns (like bottle in a bottle of wine), and the like, which also co-occur with quantitative clitic pronouns, will not be treated here, as they are the topic of other chapters (see also Measure Phrases and Semi-Lexical Nouns; Partitive Constructions).

Constructions containing a quantity item, henceforth "quantified expressions," raise a number of questions that can be clustered into three main issues: the headedness of the quantified expression, the status of the partitive PP co-occurring with the quantifier, and the analysis of quantitative clitic pronouns such as French en, Italian ne, Dutch er, Czech jich, which pronominalize a subpart of a quantified expression.

This section is devoted to introducing the leading questions to be addressed in this chapter.

Since quantified expressions like those in (1) constitute a special kind of nominal expression, it is important to establish whether they are DPs or the projection of a different category, for example QPs:

(1) a. three/many boys

b. all/both boys

c. some boys

d. each boy

In this respect, the first issue to be settled is whether the quantity item in all or some of the constructions in (1) is a modifier or a functional head in the extended projection of the noun, or whether it is in an independent projection - say, QP - external to the extended projection of $\mathrm{N}$. 
Insertion of a determiner, as in (2)-(5), roughly divides quantity items into three groups: (i) those that can be preceded but not followed by a determiner, such as three and many in (2), (ii) those that can/must be followed by a determiner, such as all and both in (3), and (iii) those that can never co-occur with any determiner, such as some in (4) and each in (5):

(2) a. the/these/his three boys

b. *three the/these/his boys

$a^{\prime}$ the/these/his many boys

$b^{\prime}$ "many the/these/his boys

(3) a. ${ }^{*}$ the $/{ }^{*}$ these $/{ }^{*}$ his all boys

b. all the/these/his boys

$\mathrm{a}^{\prime} \quad$ "the $/{ }^{*}$ these/*his both boys

$b^{\prime}$ both *the/these/his boys

(4) a. $\quad{ }^{*}$ the $/{ }^{*}$ these $/{ }^{*}$ his some boys

b. *some the/these/his boys

(5) a. ${ }^{*}$ the $/{ }^{*}$ these $/{ }^{*}$ his each boy

b. *each these/his boys

A first question is to establish the structural position of the different quantifiers. There are two possible lines of analyses: either to unify the structural position of the quantity items in (1) and (2)-(5) and attribute the different word orders to different properties of each item, or to assume that the quantity items in (1) are in the same structural position, while the quantity items occupy different positions in (2). This latter option implies that three and many in (1a), (2a), and (2a') are in different positions, while all and both in (1b), ( $3 \mathrm{~b})$, and ( $\left(3 \mathrm{~b}^{\prime}\right)$ occupy the same position.

Quantifiers can also co-occur with a "partitive $\mathrm{PP}$ " introduced by of as in (6):

(6) a. three/many of the boys

b. all/both of the boys

c. some of the boys

d. each of the boys

A second question is whether (1) and (6) are derived from one and the same structure or not. Here there also two lines of analysis. On the one hand, it seems advantageous to unify the two structures, trying to motivate the co-occurring appearance of the preposition and the definite determiner:

(7) a. many (of the) boys

b. many of * (the) boys

c. many ${ }^{*}$ (of) the boys

On the other hand, possible number mismatches as in one of the boys and extraction facts argue counter a unification hypothesis of (1) and (6). 
Some quantity expressions can co-occur with a partitive clitic: compare French en as in (8), Italian ne, Dutch er, Czech jich, and so on:

(8) $\mathrm{J}^{\prime}$ en ai vu deux.

I EN have seen two

A third question therefore concerns the category of these clitic pronouns. Here, the main problem is to establish whether the source of (9) is (9a) or (9b); in other words, whether in French, the quantitative clitic en in (9) resumes the indefinite noun garçons in (9a), the partitive PP de ces garçons in (9b), or even a different constituent:

(9) a. J' ai vu deux garçons.

I have seen two boys

b. J' ai vu deux de ces garçons.

I have seen two of these boys

The answer to this question obviously depends on the answers given to the previous ones.

A related question for French is the nature of the null category which can appear in certain contexts where the clitic pronoun is ungrammatical, as in the subject position in (10a), or optional, as in the object position in (10b):
a. Deux (*en) sont arrivés.
Two have arrived
b. $\mathrm{J}^{\prime}$ (en) ai vu quelqu'un.
I have seen some

The chapter is organized as follows. Section 2 offers an overview of the different approaches to the internal structure of quantified expressions. Section 3 discusses the partitive PP distinguishing it from other types of apparently partitive PPs. Section 4 turns to quantitative clitics. Section 5 focalizes on the null category that can be found in quantified expressions.

\section{The structure of quantified expressions}

Let us first address the questions related to the categorial status of quantified expression in (1)-(6). The literature on this has often treated the questions in (11) as tightly related to each other:

(11) a. What is the head of a nominal expression containing a quantity item such as those in (1)-(6)?

b. What is the categorial status and the structural position of the quantifier in (1) and (6)? 
c. Is there a difference in categorial status and/or structural position between

(i) a quantity item that is neither preceded nor followed by a determiner as in (1);

(ii) a quantity item preceded by a determiner as in (2a) and (2a');

(iii) a quantity item followed by a determiner as in ( $3 b)$ and $\left(3 b^{\prime}\right)$ ?

d. Is there a syntactic relation between (1) and (6), and, if so, of what kind?

We will see that (11a) and (11b) are directly related, whereas (11c) and (11d) are independent from one another.

Question (11a) has in principle the two possible answers in (12):

(12) a. The head of the quantified expression is the noun.

b. The head of the quantified expression is the quantity item.

The literature up to the late 1980s, to be discussed in sections 2.1-2.2, did not distinguish between lexical and functional categories. In that framework, the quantity item is taken as either a modifier of the noun (determiner or adjective) or something external to the nominal expression. In the past two decades, the discussion on the lexical/functional distinction opens up a new way of looking at the matter, so that question (11b), concerning the categorial status of quantity items, enters into play. In this perspective, the option in (12a) raises the question as to whether the quantity item is a maximal projection merged as a modifier of $\mathrm{N}(\mathrm{P})$, or a functional head (in the extended projection of $\mathrm{N}$ ), while (12b) raises the question as to whether the quantity item is the highest functional head in the nominal expression or an autonomous head external to the nominal expression. This is discussed in section 2.3. Question (11c) regards the merging point of the quantity item (irrespective of its head vs. maximal status), and can be answered in three different ways, as listed in (13):

(13) a. The quantity item is higher than D.

b. The quantity item is lower than $\mathrm{D}$.

c. The quantity item is in D.

d. The quantity item is inserted lower than $\mathrm{D}$ and then moved to a higher position.

In section 2.3, we show that there is no simple answer to (11c) and that the proposals to account for the word orders arising with the co-occurrence of quantity items and determiners are quite different.

Finally, any of the choices above can interact with the two possible answers to (11d) given in (14):

(14) a. The of PP in (6) has the same status as the noun in (1).

b. The of PP in (6) and the noun in (1) are inserted at different merging points.

Question (11d) was the focus of the literature in the 1970s. 
In the course of the past five decades of studies in generative grammar, almost all the possibilities mentioned in (11)-(14) have been explored. In the rest of this section, we present some of what we consider the most significant proposals on these issues in chronological order, highlighting the empirical advantages and drawbacks of each in turn.

\subsection{Extended Standard Theory proposals}

In the 1960s and 1970s, phrase-structure rules did not distinguish between adjectives and determiners such as demonstratives or quantifiers. These were all considered (maximal) elements merged with $\mathrm{N}$ building $\mathrm{N}$-bar levels. The first proposals address the question of whether it is possible to derive simple quantified expressions such as those in (1) and quantified expressions containing a partitive PP such as those in (6) from one and the same deep structure. Jackendoff (1968) and Chomsky $(1970,200)$ claim that (1) and (6) have the same deep structure. Selkirk (1977) calls this the "Hidden Partitive Hypothesis" and challenges it in favor of a "Simple Noun Phrase Hypothesis", in which a PP is assumed only when overtly present. Milner's (1978) in-depth study of quantitative clitic en in French provides motivated answers to most of the questions listed in (11).

\subsubsection{The Hidden Partitive Hypothesis}

Jackendoff's (1968) main aim is to propose one and the same deep structure for three different groups of quantity items: ${ }^{1}$ group I contains quantity nouns, such as $a$ group, a herd, a wagonload, and so on; group II contains strong quantifiers such as some, each, few, all, both, and also which; group III only includes cardinals and socalled (vague) numerals such as a few, many, one, and three. The three groups have in common that the partitive PP co-occurring with the quantity item must contain a mass or a plural nominal expression (15), and cannot be quantified itself (16):
a. *a group of the man
b. *each of the garbage can
c. *three of the book

(16) a. *a group of some men

b. *some of all the men

c. *one of few of the beetles

Jackendoff points out that the quantity items in group I and III can be preceded by an article (17a) and (17c), while those in group II cannot (17b):

(17) a. the group(s) of men

b. *the some men

c. the three men

He also observes that definite articles can only appear once in the construction (18a) versus (18c) and (19a) versus (19c), unless the nominal expression embedded in the PP contains a relative clause, as in (18d) and (19d): 
(18) a. the group of men

b. a group of the men

c. *the group of the men

d. the group of the men that had already left

(19) a. the three men

b. three of the men

c. *the three of the men

d. the three of the men you met yesterday

The obvious $\mathrm{N}$ status of the quantity nouns in group $\mathrm{I}$ is extended to vague numerals and weak quantifiers (group III), while strong quantifiers in group II are analyzed as being Det and $\mathrm{N}$ at the same time, since they do not co-occur with articles and co-occur with the partitive PP. Jackendoff $(1968,428)$ proposes an of-deletion transformation for groups II and III, in order to derive simple quantified expressions such as some men and three men. It is not clear why this transformation should not apply to group I.

\subsubsection{The Simple Noun Phrase Hypothesis}

Selkirk (1977) shows that simple quantified expressions and those embedding a partitive phrase are different and that the latter cannot be transformationally derived from the former. Her strongest argument is the different result of PP extraposition in (20). The reason for the ungrammaticality of (20b) should not be directly attributed to the definiteness of those reviews (given that (20c) is perfectly acceptable) but to a violation of the cycle, which does not occur in (20a):

(20) a. Two reviews have been reprinted of Helen's first symphony.

b. *Two of those reviews have been reprinted of Helen's first symphony.

c. Those reviews have been reprinted of Helen's first symphony.

This suggests that the quantified expression in (21a), parallel to (20a), is structurally simpler than the one in $(21 b)$, which is parallel to $(20 b)$ :

(21) a. Two reviews of Helen's first symphony have been reprinted.

b. Two of those reviews of Helen's first symphony have been reprinted.

A similar argument is given by Milner $(1978,71)$ for French. While extraction out of the partitive PP is ungrammatical in (22), extraction out of the constituent that follows the quantifier in (23) is possible. This implies that the XP in (23) cannot be the PP we find in (22). Note that this also holds of (23b) in spite of the presence of the preposition de:

(22) ${ }^{*}$ C'est de Zola que j'ai lu [deux [pp des livres [pp de Zola]]]. it is of Zola that I have read two of-the books

(23) a. C'est de Zola que j'ai lu [deux [xP livres [PP de Zola]]]. it is of Zola that I have read two books 
b. C'est de Zola que j'ai lu [beaucoup [xp de livres [pp de Zola]]]. it is of Zola that I have read many of books

The conclusion that the nominal constituent following the quantifier (henceforth "quantitative phrase") is different from the partitive PP is confirmed by the fact that they cannot be coordinated, as shown in French (24):
a. J'ai
reçu
beaucoup de voisins
et $d^{\prime}$ amis.
I have received
many
of neighbours
and of friends
b. J'ai reçu
I have received
beaucoup
de mes voisins
et de mes amis.
c. 'J'ai reçu
of my neighbours
and of
et $\mathrm{d}^{\prime}$ amis.

Milner (1978, $81 \mathrm{ff}$.) suggests that in (23), the quantitative phrase livres or de livres is an $\mathrm{N}^{\prime}$, while the partitive phrase des livres is an $\mathrm{N}^{\prime \prime}$. This is also shown by the fact that personal pronouns, which are certainly full nominal expressions ( $\mathrm{N}^{\prime \prime}$ in the theory of the time), can only appear as partitive phrases and not as quantitative phrases, as shown by French in (25):

$$
\begin{aligned}
& \text { un de nous/vous/eux } \\
& \text { one of us/you/them }
\end{aligned}
$$

A further argument against the Hidden Partitive Hypothesis is discussed in Belletti $(1979,1546)$. The two Italian sentences in (26) have different semantic properties. In (26a), the books that have been read are five and coincide with the books that have been lent. In (26b), the books that have been read are a subset of the books that have been lent, which are presupposed to be more than five:
a. Ho
letto cinque libri
b. Ho
letto cinque dei libri
che mi avevi prestato.
[I] have read five (of the) books
che mi avevi prestato.
that [you] to.me had lent

If the two constructions in (1) and (6) do not have a common deep structure, the status of the first part of the construction with a partitive phrase remains unknown. Contra Jackendoff (1968), Jackendoff (1977, $110 \mathrm{ff}$.) adopts the Simple Noun Phrase Hypothesis and analyzes many as a determiner under $\mathrm{N}^{\prime \prime}$, introducing a null $\mathrm{N}$ in the partitive construction, as in (27):

$$
\left[\mathrm { N } ^ { \prime \prime } [ \mathrm { Q } ^ { \prime \prime } \text { many } ] \left[\mathrm{N}^{\prime},\left[\mathrm{N} \text { PRO] of }\left[\mathrm{N}^{\prime \prime \prime} \text { the men }\right]\right]\right.\right.
$$

A similar structure is suggested for Italian by Rizzi (1979), with the difference that the partitive PP is not included under $\mathrm{N}^{\prime}$, but at a higher level:

$$
\left[\mathrm { N } ^ { \prime \prime } [ \text { Det } u n o ] \left[\mathrm{N}^{\prime} \text { e] }\left[\mathrm{P}^{\prime \prime} \text { dei tuoi libri }\right]\right.\right.
$$

Rizzi's analysis is based on phonosyntactic evidence from Italian. In (29a) and (28b), we observe the obligatory truncation of the masculine singular determiner uno $>$ un 
when it precedes a consonant such as [1]. Note that this occurs both when uno immediately precedes the noun as in (29a) and when it precedes the prenominal adjective, as in (29b). In (29c), where ne occurs, the determiner can only have the form uno, independently of the presence of the adjective. This is analyzed by Rizzi as evidence that truncation does not occur when the determiner is followed by an empty category. The ungrammaticality of (29d) would be unexpected if ne was only resuming the noun. Rizzi concludes that $n e$ is an $\mathrm{N}^{\prime}$, and the adjective that co-occurs with it is postnominal, attached at a higher level (see section 4.3 for further discussion):
a. Ho letto
[I] have read
b. Ho letto a book very.long un*(o) lunghissimo libro. $u^{*}(\mathrm{o})$ libro lunghissimo. [I] have read
c. Ne ho letto a very.long book [I] NE have read one very.long
d. ${ }^{*}$ Ne ho letto un lunghissimo [ne]. [I] NE have read a very.long

Rizzi extends the analysis to partitive PPs, with which truncation never occurs in Italian, showing that there is an empty category between the determiner and the partitive PP:
Ho letto
$\mathrm{un}^{*}(\mathrm{o}) \quad[e]$
dei tuoi libri.
[I] have read one
of your books

Milner (1978, 83 ff.) further points out that the quantifier occurring with the partitive phrase must be a pronoun, not a determiner, in the pairs quelque/quelques-uns 'some' and chaque/chacun 'each'. The same is true in Italian (31):
a. ogni/qualche
ragazzo
vs. ${ }^{*}$ ognun $/{ }^{*}$ qualcun ragazzo each/some boy
b. ${ }^{*}$ ogni/"*qualche di loro vs. ognuno/qualcuno di loro each/some of them

Other pronominal forms can co-occur with the partitive phrase, such as celui or lequel in French, as in (32):
a. Celui des livres de Zola que j'ai lu. the one of-the books of Zola that I have read
b. Lequel de ces livres avez-vous lu? which of these books have you read?

In certain contexts, the noun in $\mathrm{N}^{\prime \prime}$ is explicit, like peintures in French (33):

$\left[\mathrm{N}^{\prime \prime}\right.$ Quatre peintures]
$\begin{aligned} & \text { four pictures } \\ & \text { retrouvées. }\end{aligned}$


The quantitative clitic en can co-occur with a partitive phrase, as in French (34):
a. J'en ai pris
un kilo
de celles-ci.
b. J'en ai pris
dix
de celles-ci.
c. J'en ai pris
beaucoup de celles-ci.
I EN have taken
a kilo/ten/many of these

In conclusion, EST studies have arrived at an important generalization: the quantitative phrase must be distinguished from the partitive phrase, thus arguing in favour of the answer in (14b).

\subsection{GB proposals}

Government and Binding approaches are driven by the search for general principles of UG that constrain movement of constituents and the occurrence of anaphoric elements. Phrase-structure issues are no more crucial in this period and remain in the background. Quantified expressions in French, Italian, and Dutch become a focus of general interest because the extraction of the quantitative clitic is constrained by the general principles of Government and Binding (see Belletti and Rizzi 1981; Burzio 1986). The core cases are given for Italian in (35)-(37). (35) shows that extraction of $n e$ is impossible from a preverbal subject, and an empty category is found instead. In (36) ne is obligatory if it binds an empty category in object position. The selected direct object in (36) contrasts with the adverbial phrase in (37):

(35) a. Tre settimane passano rapidamente. three weeks elapse rapidly

b. ${ }^{*}$ Tre [ne] ne passano rapidamente. Three NE elapse rapidly

c. Tre $[e]$ passano rapidamente. Three elapse rapidly

(36) a. Gianni trascorrerà tre settimane a Milano. Gianni will spend three weeks in Milan

b. Gianni ne trascorrerà tre [ne] a Milano. Gianni NE will spend three in Milan

c. *Gianni trascorrerà tre $[e]$ a Milano. Gianni will spend three in Milan

(37) a. Gianni è rimasto tre settimane a Milano. Gianni remained three weeks in Milan

b. *Gianni ne è rimasto tre [ne] a Milano. Gianni NE remained three in Milan

c. ${ }^{*}$ Gianni è rimasto tre $[e]$ a Milano. Gianni remained three in Milan

Belletti and Rizzi (1981) reduce the [e] versus ne alternation in (35)-(37) to general requirements of Proper Binding (see Fiengo 1974). In the case of subjects, ne does not c-command its trace, hence the ungrammaticality of (35b). In the case of objects, ne 
c-commands its trace, hence the grammaticality of (36b). In the case of adjuncts, ne extraction causes a Subjacency violation, hence the ungrammaticality of (37b). As for the distribution of the null category $[e]$ inside the quantified expression, Belletti and Rizzi take it to be PRO (as originally proposed by Kayne 1979, appendix). It is allowed in subject position (35c), but forbidden in object and adjunct position, where it is governed by the verb, (36c) and (37c).

In Italian, postverbal subjects of unaccusative verbs behave like objects, as expected:

(38) a. Sono passate tre settimane.

are elapsed three weeks

b. Ne sono passate tre [ne].

c. $\quad{ }^{*}$ Sono passate tre $[e]$.

With postverbal subjects of transitive and intransitive verbs, neither $[e]$ nor $n e$ are possible, the former because it is governed by the verb, the latter because it causes a violation of Subjacency:

(39) a. Hanno parlato tre ragazze.

have spoken three girls

b. ${ }^{*} \mathrm{Ne}$ hanno parlato tre [ne].

c. * Hanno parlato tre $[e]$.

In PPs, ne is ungrammatical, and the null category is marginal:

(40) a. Mi sono concentrato su alcuni problemi.

[I] concentrated on some problems

b. *(Di questi problemi,) me ne sono concentrato su alcuni [ne]. (of these problems) [I] NE concentrated on some

c. ?(Di questi problemi,) mi sono concentrato su alcuni $[e]$. (of these problems) [I] concentrated on some

(40b) represents a violation of Subjacency; $[e]$ in (40c) is marginally accepted due to the non-governing nature of the preposition. In sections $4-5$ we will come back to the nature of the empty category and its interpretation.

Belletti and Rizzi's analysis of Italian can be extended to Czech, where the genitive clitic jich can be extracted from subjects and objects, as in Toman $(1986,131)$ :
a. Tehdy jich nêpolik podepsalo ten dopis. then of.them some signed that letter 'Then some of them signed that letter.'
b. Tehdy jich Petr nalezl pêt. then of.them Petr found five 'Then Peter found five of them.

Czech has second-position clitics. Hence, the clitic c-commands its trace even when it is extracted from the subject position. 


\subsection{The functional structure of quantified expressions}

At the end of the 1980s, the study of the internal structure of noun phrases became a focus of research based on a wider set of languages, including Hungarian (Szabolcsi 1987), Hebrew (Ritter 1988), and Romanian (Grosu 1988), among many others. The major topic of this research is the investigation of functional heads inside the nominal expression, which is parallel in many respects to the structure of the sentence. A related trend of research follows Cinque (1994), in taking adnominal adjectives to fill functional specifiers parallel to adverbs in the clause. Both issues are central to the internal structure of quantitative and partitive phrases, since in the approaches reviewed earlier, the distinction between determiners and adjectives was not clear, and quantifiers were considered to be part of this large class of prenominal modifiers.

\subsubsection{The DP hypothesis}

Abney $(1987,271)$ places quantifiers in D, namely in a head position. In order to derive their co-occurrence with possessors in Hungarian (42) (also see Szabolcsi 1987) and their (almost) complementary distribution with possessors in English (43), Abney proposes the constraint in (44), which applies to English, but not to Hungarian:

(42) a. Peter minden kalapja

b. Peter ezen/azon kalapja

c. Peter valamennyi kalapja

d. Peter mindket kalapja

e. Peter semelyik kalapja

(43) a. John's every wish

b. *John's this/that wish

c. *John's each wish

d. *John's both wishes

e. *John's neither wish

(44) Agr in D does not co-occur with lexical determiners.

Abney also proposes that other quantifiers are adjectives that occupy a head position lower than D and higher than descriptive adjectives, as in (45) (Abney 1987, $287,312)$ :

(45) [DP these [QP exceedingly [Q' many [AP very beautiful [NP women]]]]]

The position of many in (45) is also assumed for cardinals and other quantifiers and supported by a parallel between quantifiers and comparative adjectives which also co-occur with a partitive PP. Abney $(1987,344)$ takes this PP to be the complement of an empty $\mathrm{N}$ that is in the complement of $\mathrm{Q}$ in (46) or of comparative $\mathrm{A}$ in (47) (Abney's example (413)):

(46) [DP [D many] [NP [N $e]$ [of the women]]] 
[DP the [AP better [NP [N $e$ ] [of the two]]]]

The parallel between comparative and superlative structures, on the one hand, and partitive structures, on the other, is not new in the literature. Bresnan (1973) and Milner $(1978,121)$ had, however, suggested that the partitive phrase is the complement of the degree morpheme and not of the adjective or of the noun. Evidence for this is the fact that the partitive PP does not appear to form a constituent with the NP, either with a superlative (48a) or with a quantifier (48b):

(48) a. *Books of those you lent me, I've read only the best.

b. *Books of those you lent me, I've read only some.

Furthermore, while in (49), the partitive PP can co-occur with the lexical nouns, in (50) it cannot occur with a quantifier preceded by a determiner (irrespective of the position of the lexical noun):

(49) a. the best books of those you lent me

b. many books of those you lent me

(50) a. *the many books of those you lent me

b. *the many of the books you lent me

The data in (48b), (49b), and (50a) are problematic for all approaches that claim that the partitive PP forms a constituent with the quantitative phrase, as we will observe in section 3.

\subsubsection{The QP hypothesis}

Although not interested in the internal structure of quantified expressions, Sportiche (1988) is the first to propose that a quantifier is external to the nominal expression. Sportiche claims that the universal quantifier is adjoined to NP. This proposal, interacting with the hypothesis that the subject is generated VP-internally (Koopman and Sportiche 1985; 1991), provides a derivational analysis of floating quantifiers (see Quantifier-Float), as in French (51):

(51) a. [IP [NP Les enfants] ont [VP [NP tous [NP les enfants]] vu ce film]].

b. [IP [NP The children] have [VP [NP all [NP the children]] seen this film]].

In (51), the discontinuous order of the quantified expression is derived by movement of the subject from the VP-internal position to SpecIP, leaving the quantifier in its merge position.

Adopting the DP hypothesis, Shlonsky (1991) for Hebrew and Giusti (1991a) for Italian rephrase Sportiche's proposal by suggesting that the quantifier is the head of a QP projection which embeds DP. In addition to the discontinuous order in (51) (see also (53), (62), and (77) below), they observe that the quantifier and the rest of the constituent can also appear in an inverted order (see (52a) and (54)-(57) and (60)-(61) below for different languages). The QP hypothesis provides a 
left-edge to which the DP can move as in (52a), obtaining the inverted order, and through which the DP can extract, as in (52b), obtaining the discontinuous order:
a. $\quad\left[\mathrm{QP} D P\left[\mathrm{Q}^{\prime} \mathrm{Q}\right.\right.$ DP] inverted order

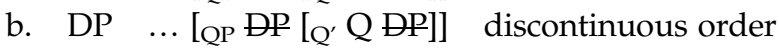

The fact that the two options in (52) are never found with other determiners is one of the crucial reasons to assume that $\mathrm{Q}$ is a head external to the DP and not filling the head D.

Shlonsky (1991) motivates his proposal on the basis of the agreement marking that appears on the head Q in Hebrew when the DP is moved to the left, leaving $\mathrm{Q}$ in situ, as in (53b):

a. [QP kol [DP ha-yeladim]] yašnu. all the children slept

b. [DP ha-yeladim] yašnu [QP ha yeladim [Q' kulam [DP ha yeladim]]]. the children slept all

In Hebrew, the agreeing form is also found when SpecQP is the final landing site of the DP, producing an inverted order inside the QP:

a. [QP kol [DP ha-yeladim]] Pohavim le-saxek.

all the children love to play

b. [QP [DP ha-yeladim] [Q' kulam [DP ha yeladim]]] ?ohavim le-saxek. the children all love to play

Giusti (1991a) extends Shlonsky's movement analysis to personal pronouns which occur before the quantifier in various languages, such as French (55), English (56), and optionally Italian (57):
a. ${ }^{*}\left[\mathrm{QP} \quad\left[\mathrm{Q}^{\prime}\right.\right.$ tous [DP eux $\left.]\right]$
b. [QP $[\mathrm{DP}$ eux $]\left[\mathrm{Q}^{\prime}\right.$ tous [DP eux]]]
a. ${ }^{*}[\mathrm{QP}$
[Q' all [DP them]]]
b. [QP [DP them] [Q' all [DP them]]]
a. $[Q P$
[Q' tutti [DP loro]]]
b. [QP [DP loro] [Q' tutti [DP lore]]]

The two possible orders in Italian favor different readings: the inverted order favors a collective reading, while the basic order allows both collective and distributive reading.

In Italian, if the pronoun is a clitic, it moves out of the QP giving rise to discontinuous order:
Li ho visti
[QP tutti [DP li]].
[I] them have seen all 
Extraction out of QP (discontinuous order) and movement to specQP (inverted order) is not restricted to universal quantifiers. Giusti (1990) shows that so-called Split Topicalization in Germanic (see van Riemsdijk 1989; also see Split Topicalization) is a sort of quantifier floating construction, which is allowed from both subject and object positions: ${ }^{2}$

(59) a. Kinder haben [QP viele [DP Kinder] ] angerufen. children have many called

b. Kinder habe ich [QP viele [DP Kinder]] getroffen. children have I many met

Giusti (1994) further shows that in Hebrew, the agreement phenomenon seen in (53)-(54) above is also found with existential quantifiers, as in (60):

(60) a. [QP meat [DP yeladim]]/[QP meat [DP yeladot]] Pohavim le-saxek. few boys few girls love to play

b. [QP [DP yeladim] [Q' meatim [DP yeladim]]]/[QP [DP yeladot] boys few.M.PL/ girls [Q, meatot [DP yeladot]]] ?ohavim le-saxek. few.F.PL love to play 'Few boys/few girls love to play.'

In Romanian, DP-movement to SpecQP (inverted order) is found with both universal and existential quantifiers, provided the DP is not modified:
a. Am văzut
[QP [DP copiii] [Q' toți [DP eOpiii]]].
[I] have seen
children-the all
b. Am văzut

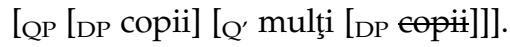
[I] have seen
children many

Parallel to what has been noted for (57) above, a collective reading is preferred in the inverted order. This may be the cause of the incompatibility of the inverted order with individual-level predicates (cf. ${ }^{*}$ copii mulţi sunt inteligenti i 'students many are intelligent' suggested to us by an anonymous reviewer).

Finally, the proposal that universal and existential quantifiers project a similar structure allows Cardinaletti and Giusti (1992; 2006) to analyze Italian quantitative $n e$ in (62) as pronominalizing a DP (see section 4.4.2 below), parallel to accusative $l i$ (them.M) in (58):

(62) Ne ho visti

[I] NE have seen many

Giusti's hypothesis that universal and existential quantifiers are heads embedding a DP and projecting a Specifier (opposite to determiners and adjectives, which are internal to DP) can account in a principled way for (53)-(62), which would otherwise appear idiosyncratic.

Cardinaletti and Giusti (1992; 2006) propose that Qs are (semi-)lexical categories with selectional properties. Existential quantifiers have a dyadic argument structure 
with two internal arguments: the indefinite DP (called quantitative DP) and the partitive PP: ${ }^{3}$

(63) $\left[\mathrm{QP}^{\prime}\left[\mathrm{Q}^{\prime}\left[\mathrm{Q}^{\prime}\right.\right.\right.$ many [DP boys]] [PP of those that you met yesterday]]

This analysis is motivated by the fact that the selectional properties of $Q$ determine both the features on the quantitative DP and the occurrence of the partitive PP. For example, universal quantifiers such as tutti 'all' and entrambi 'both' select a definite DP as in tutti $i$ ragazzi 'all the boys', and do not select a partitive PP as in *tutti dei ragazzi 'all of the boys'. ${ }^{4}$ Existential quantifiers such as molti 'many' and alcuni 'some' and distributive quantifiers such as ogni 'every' and ciascun(o) 'each' can select both a quantitative DP and a partitive PP, as in molti ragazzi di quelli che conosco 'many boys of those I know' and ogni ragazzo di quelli che conosco 'every boy of those I know'.

Another piece of evidence in favour of (63) is the particular English construction given in (65), where many occurs at the left side of a determiner, parallel to all in (64), and differently from many in (2a') above:

(64) a. all the good students

b. all the other men

(65) a. many a good student ${ }^{5}$

b. many another man

Similarly, in the Ladin construction discussed in Benincà and Haiman (1992) and reported in (66a), from Badiot, and (66b), from Gardena, the quantifier øna/una co-occurs with the indefinite determiner $n a$ :
a. Da øna na skwadra (eson pasa a trèj). from one a team ([we] passed to three) 'From a team we grew to three.'
b. (l'èrt kuntsètuala), una na rama $\mathrm{dl}$ èrt visiva (the art conceptual), one a branch of-the art visual 'conceptual art, one branch of visual art'

The data in (65) and (66) can be captured in structure (63) in a parallel way to universal quantifiers, which occur with a definite determiner, compare (67a) and $(67 b, 67 c)$ :
a. [QP [Q all]
[DP [D the] [NP men]]]
b. [QP [Q many] [DP [D a] [NP man]]]
c. [QP [Q øna] [DP [D na] [NP skwadra]]]

In simple quantified expressions such as many men, the additional, quite costless assumption is that a null indefinite determiner occurs in the DP complement of an existential $Q$, as in (68):

(68) [QP [Q many] [DP [D Ø] [NP men]]] 
Universal quantifiers can also co-occur with a null determiner in English (69a), but this is not possible in many other languages, for example Italian (69b), in which the definite determiner is obligatory:

(69) a. $\left[\mathrm{QP}_{\mathrm{Q}}[\mathrm{Q}\right.$ all $] \quad\left[\mathrm{DP}[\mathrm{D} \varnothing] \quad\left[\ldots\left[{ }_{\mathrm{NP}}\right.\right.\right.$ men $\left.\left.\left.]\right]\right]\right]$ are mortal.

b. [QP [Q tutti] [DP [D gli] [... [NP uomini]]]] sono mortali.

The null determiner in (69a) is the same found in kind-referring nominal expressions, hence it is independent of the presence of the quantifier (see Matthewson 2001). This null determiner is very restricted in Italian (see Longobardi 1994; Chierchia 1998) (see also Bare Nouns).

Summarizing the results of this section, the QP hypothesis claims that $\mathrm{Q}$ is a head external to DP and projects a full QP. This hypothesis accounts for the facts in (70), which build a diagnostics for the $Q$ status of a quantity item:

(70) Diagnostics for quantifiers:

a. Qs can precede (definite or indefinite) articles.

b. Different classes of Qs correlate with the (in)definiteness of the embedded DP.

c. Qs can co-occur with pronouns.

d. Qs allow leftward movement of the DP to an immediately adjacent position which builds a constituent with Q and can straightforwardly be analyzed as SpecQP.

e. Qs can occur in discontinuous position in a number of languages, unlike nominal modifiers and determiners.

f. Qs can co-occur with partitive PPs.

\subsubsection{The AP hypothesis}

The QP hypothesis does not capture the fact that some quantity items can be preceded by a determiner, as in the many boys (2a'). These items can be analyzed as adjectives occurring in the specifier of a functional projection (AgrP) inside the DP, as in (71) (see Giusti 1991a; 1993):

(71) [DP the [AgrP [QAP many]... [NP boys]]]

This hypothesis is strictly syntactic and does not aim at deriving the weak (adjectival) versus strong (proportional) reading of quantifiers, in the sense of Milsark (1977). In fact, not all weak quantifiers can appear after a determiner and, vice versa, not all strong quantifiers are ungrammatical after a determiner. Furthermore, not all quantity items behave like many in having a double categorial status as quantifier and adjective.

First, not all weak quantifiers can be adjectives. A weak quantifier like some, which appears in there-sentences in (72a), cannot occur with the determiner (72b) (see (4a)), differently from many and cardinals:

(72) a. There are many/three/some students.

b. The many/three/ ${ }^{*}$ some students that I know are all lazy. 
Second, in some languages strong quantifiers can occur after a determiner, unlike all, both, most in English (see (3a, 3a')).

In German (73b) and Dutch (73c), for example, the counterparts of the English strong quantifier most in (73a) are adjectival in nature. Meisten in (73b) and meeste in (73c) clearly display adjectival morphology and must be preceded by a (definite) determiner:

(73) a. (*The) most children are nice.

b. Die meisten Kinder sind nett.

c. De meeste kinderen zijn aardig.

This is also the case of the German universal quantity adjective ganzen 'all' in (74a) and can be the case of beide 'both' in (74b):
a. Die ganzen the all
Kinder sind da.
b. Die beiden children are here the both

$\begin{array}{lll}\text { Kinder } & \text { sind da. } \\ \text { children are here }\end{array}$

While in German, ganz can only have adjectival status $(75 a){ }^{6}$ beide $(n)$ is ambiguous between $A$ and $Q$ status (75b):

(75) a. *Ganze Kinder sind da.

b. Beide Kinder sind da.

Giusti $(1993,103)$ derives the lack of a determiner following the quantifier beide in (75b) through incorporation of the morphology on $\mathrm{D}$ to $\mathrm{Q}$ when $\mathrm{Q}$ and $\mathrm{D}$ are adjacent, as represented in (76a). This is clear with all in German, which may be uninflected when D is overt, as in (76b), can incorporate the morphology in D, as in (76c) parallel to $(76 \mathrm{a})$, or can have independent morphology from the overt definite article, as in (76d):

(76) a. [QP beid- [DP [D -e] [NP Kinder]]]

b. [QP all [DP [D die] [NP Kinder]]]

c. [QP all- [DP [D -e] [NP Kinder]]]

d. [QP alle [DP [D die] [NP Kinder]]]

This proposal is supported by the fact that when the DP is extracted out of the quantified expression, as in German (77a), the determiner must be overt. It is reasonable to extend the same analysis to English $(77 \mathrm{~b})$ :

(77) a. [DP Die Kinder] sind [QP [DP die Kinder] [Q' beide [DP die Kinder]]] da.

b. [DP The children] are [QP [DP the children] [Q, both [DP the children]]] here.

The idiosyncrasy in the categorial status of quantity items across languages is expected under the hypothesis that the category of these elements is independent of their universal versus existential meaning. In each language, a given quantity 
item is assigned either category or both. What is correctly expected is that the syntactic behavior of the item directly depends on its categorial status and not on its semantic value.

Romanian provides an interesting minimal pair (see Giusti 1991b; 1993; 1995). Dual universal quantity can be expressed either by a quantifier, amîndoi, or by a quantity adjective, ambii. Amîndoi is parallel to toţi 'all' in embedding a full definite $\mathrm{DP}$, while ambii is a prenominal adjective. ${ }^{7}$ In (78) we observe that the enclitic article is on the noun (78a) or on the prenominal adjective (78b), but never on the quantifier (78c). This shows that amindoi and toţi are not part of the extended projection of the noun; rather, they immediately embed a DP:
a. Au venit amîndoi / toţi băieţii frumoşi. have arrived both / all boys-the nice
b. $\mathrm{Au}$ venit amîndoi / toți frumoşii băieţi. have arrived both / all nice-the boys
c. ${ }^{*} \mathrm{Au}$ venit amîndoii / toții băieți (frumoşi). have arrived both-the / all-the boys nice

Quite the opposite holds in Romanian of the quantity adjective ambii, which is always inflected for the enclitic article ((79b), (79c)). It behaves like other prenominal adjectives such as biet 'poor', which must also bear the definite article in definite descriptions. Parallel to bief̧ii, ambii precedes other prenominal modifiers as in (79c):
$\begin{array}{lllll}\text { a. }{ }^{*} \text { Au } & \text { venit } & \text { ambi/bieți băieţii } & \text { (frumoşi). } \\ \text { have } & \text { arrived } & \text { both/poor } & \text { boys-the } & \text { nice }\end{array}$
b. $\mathrm{Au}$ venit
ambii/bieţii
băieţi
c. $\mathrm{Au}$ venit
ambii/bieţii
(frumoşi) băieţi.
have arrived
both-the/poor-the nice
boys

The combination of the QP hypothesis and the AP hypothesis predicts the cooccurrence of two quantity items in one and the same nominal expression, as in Italian (80) and English (81). The proposal is also sufficiently restricted to predict the ungrammaticality of some logically possible combinations, as in Italian (82):

(80) a. tutti questi

b. entrambi

questi due

compiti da correggere ragazzi
a. all
these
two hundred and forty/very many
tests to check
b. some twenty
c. no
two tests to check tests
a. tutti
questi ('alcuni)
compiti da correggere
b. all these ('some) tests to check
c. twenty
(*some)
d. two
(*no)
children
tests

In this line of analysis, the reason for the ungrammaticality of (82) is not (necessarily) the semantic incompatibility between the two quantity items. It is rather the fact 
that Italian alcuni and English some and no are not adjectives and cannot appear inside the DP.

Quantity adjectives inside the partitive PP in (83) do not produce a violation of the partitive constraint (see Jackendoff 1972; Ladusaw 1982; Wilkinson 1991; Hoeksema 1996; Barker 1998; de Hoop 1997, among others), found with quantifiers in (84) (see (16) above, and Casadio 1995, fn. 3). This holds both in Italian (83a), (83c), (84a), and (84c) and in English (83b), (83d), (84b), and (84 s):
a. molti di questi duecentoquaranta
b. many of these two hundred and forty
c. tre delle poche mele
compiti da correggere
d. three of the
few apples
tests to check
che ho
that I have
a. ${ }^{*}$ molti di duecentoquaranta
b. *many of two hundred and forty
c. *tre di poche
compiti da correggere
tests to check
d. *three of few
mele (che ho)
apples (that I have)

The diagnostics provided in (70) for quantifiers do not hold for quantity adjectives. When quantifiers are in object position in Italian, they allow for the extraction of a clitic pronoun, as observed in (62). This possibility does not arise with other modifiers of the noun, because the clitic resumes a full DP: quantity adjectives, as in (85b), give the same result as other adjectives in (85a). Note that ne-extraction is allowed across a definite article in $(85 \mathrm{c})$, where $n e$ binds a genitive PP:
a. $\quad{ }^{*} \mathrm{Ne} /{ }^{*} \mathrm{Li}$ ho comprati
(gli) interessanti [ne/li].
[I] NE/them have bought
b. ${ }^{*} \mathrm{Ne} /{ }^{*} \mathrm{Li}$ ho comprati
(the) interesting
[I] NE/them have bought
c. Ne ho letto
$\mathrm{i}$ tre/molti [ne/li] .
the three/many
[I] CL have read
i racconti [PP ne].
the short stories

If floating is the result of DP movement, as claimed by Sportiche (1988) and Giusti (1990) among others, it is predicted that in Romanian only the quantifiers amindoi and toţi, but not the adjective ambii (see (78)-(79) above), occur in floating constructions:

$\begin{array}{llllll}\text { (86) Băieţii } & \text { frumoşi } & \text { au venit amîndoi / toţi / *ambi(i). } \\ \text { children-the } & \text { nice } & \text { have arrived both } & \text { / all / both }\end{array}$

As in (61) above, Romanian allows a postnominal position of the quantifier. If this is due to movement of DP to SpecQP, we expect that only amindoi and toţi, but not ambii, can be postnominal. (87b) shows that ambi(-i) behaves like the prenominal adjective bieţi(-i):
a. noi
amîndoi
/ toţi
we both
/ all 


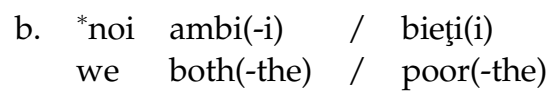

Slavic languages provide a different set of phenomena that distinguish between quantifiers and quantity adjectives, as discussed in Giusti and Leko (1996; 2001) and Leko (2009) for Bosnian/Croatian/Serbian. In (88a), the quantifier mnogo 'many' appears with a genitive DP (studenata) or strong pronoun (njih). In (88b), ih is clitic and must be extracted out of QP:
a. Vidio sam
mnogo studenata /
njih.
[I] saw CLF.AUX
many
students.GEN.PL/
them.GEN.PL
b. Vidio sam
ih mnogo.
[I] saw CLF.AUX them.CLF.GEN.PL many
"I saw a lot of them."

This is not the case of quantity adjectives in Bosnian/Croatian/Serbian, which do not assign Case and agree with the following noun as in (89a). In (89b) and (89c), it is shown that a quantity adjective cannot occur with a pronoun, irrespective of its strong or clitic nature. It can only occur in an elliptical construction without the noun (89d). Note that the forms jih and njih are ambiguously genitive and accusative plural:

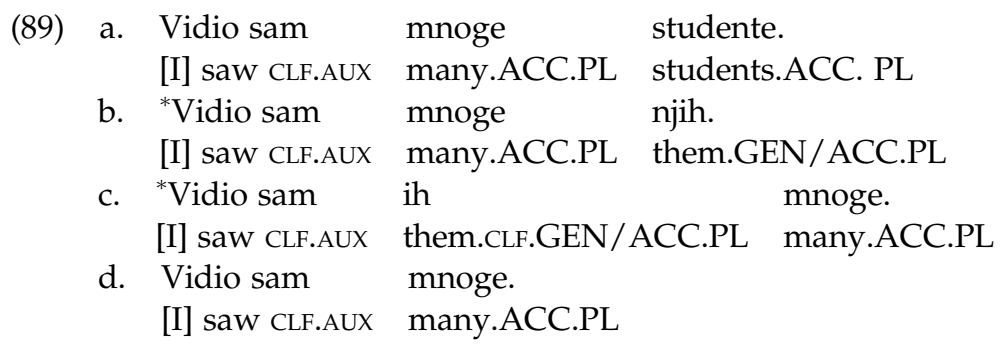

Thus, despite its being an articleless language, Bosnian/Croatian/Serbian supports our argument based on co-occurrence with a pronoun and clitic extraction in (85) above, providing a further reason to believe that it is not the presence of an article that blocks clitic extraction in Romance.

A parallel argument can be built for German. In (90) quantifiers such as alle and beide can occur with a pronoun, while the adjective ganze cannot:

(90) wir alle / wir beide / *wir ganze(n)

we all / we both / we all

Finally, quantity adjectives such as tre and molti in (91a) do not select a partitive PP (see the discussion on (50) above), contrary to their quantifier homonyms in (91b):
(91)
a. ${ }^{*}$ questi
these
b. tre/molti
tre/molti
dei partecipanti
three/many
of the participants
b. tre/molti dei partecipanti 
To summarize, we have seen that only some quantity items can occur in adjectival position. The possibility to be merged in such a position is due to their categorial status, which must be listed in the lexicon. In (92), we give the diagnostics for quantity adjectives, to be contrasted with the diagnostics for quantifiers provided in (70):

(92) Diagnostics for quantity adjectives:

a. Quantity adjectives are preceded by a determiner (in languages that have a definite article).

b. Quantity adjectives cannot occur with (overt or covert) pronouns.

c. Quantity adjectives do not allow extraction of the part of the DP that does not contain them.

d. Quantity adjectives cannot appear in discontinuous position (in languages in which adjectives cannot do so).

e. Quantity adjectives do not co-occur with a partitive PP.

\subsubsection{A unified hypothesis}

Given the discussion so far, the unification of many in many boys (see (1a)) and the many boys (see $\left(2 a^{\prime}\right)$ ) under the same label/position is not straightforward and requires argumentation. This is provided by Zamparelli $(1995 ; 2000)$, who proposes the split DP structure ${ }^{8}$ in (93), designed to capture the different interpretive properties of several types of determiners as classified in the semantic tradition of Milsark (1977) and Barwise and Cooper (1981):

$$
\text { [SDP SD [PDP PD [KIP KI [... [NP N]]]]] }
$$

The structure in (93) provides different positions for different kinds of determiners. SDP (strong determiner phrase) is the projection where both strong determiners, like demonstratives and the definite article, and strong quantifiers both, most, every, and each are directly inserted. PDP (predicative determiner phrase) is the projection where the indefinite article $a$ and weak quantifiers such as cardinals, vague numerals like many, few, and some are inserted. KIP (kind phrase) is the projection that denotes kinds, which includes all adjectival modifiers of the noun. The labels "strong determiner" and "predicative determiner" collocate Zamparelli in the semantic tradition of Milsark (1977) according to which strong quantifiers are determiners, while weak quantifiers are modifiers.

The head and specifiers of SDP and PDP are filled only once. Cardinals and articles are taken to be heads, while all other simple and complex determiners are taken to be in the specifier of the relevant projection. Complex determiners can be formed by a quantifier modified by an adverbial, as in exactly three, by a determiner and an adjective, as in a certain and the first, or by two quantifiers as in some twenty (see Zamparelli 2000, 262).

The immediate appeal of (93) is that it creates a direct syntax-semantics mapping of the well-known semantic properties of quantifiers. The ambiguity between the strong and weak reading of existential quantifiers (i.e., cardinals and vague numerals) is accounted for by assuming that they are inserted in PDP, where they trigger the weak reading, and that they can be moved to SDP where they trigger the 
strong reading. Those quantifiers which only trigger the strong reading are directly inserted in SDP. Thus, a cardinal is first inserted in the head of PDP and then moved to the head of SDP to obtain the strong reading, while a vague numeral is first inserted in SpecPDP and then moved to SpecSDP to obtain the strong reading.

In line with Longobardi (1994), Zamparelli $(2000,121)$ assumes that nominal expressions in argument positions have the complete SDP structure. In (94), we observe three possible cases in object position. In (94a) we see a strong nominal expression, in (94b) a weak nominal expression, and in (94c) a bare plural (also see Bare Nouns):
a. I am looking for
[SDP every [PDP $P D_{\text {[sing] }}$
[KIP... man]]].
b. I am looking for
IsDP SD
[PDP two
[KIP ... people]]].
c. I am looking for $[\mathrm{SDP} S \mathrm{SD}$
[PDP $\mathrm{PD}_{\text {[plural] }}$
[KIP ... people]]].

In (94a), the strong quantifier every inside SDP licenses the empty PD and identifies its [sing] feature. In (94b), the weak interpretation is obtained by keeping the quantifier in PDP. SD is empty and licensed by the verb. In (94c), the null SD is licensed and identified by the verb as in (94b), but the null PD cannot be identified by the null $\mathrm{SD}$. The identification of PD is obtained by proposing that PDP is predicated of SDP and that a null SD, if licensed, can identify a [plural] (or [mass]) feature in PD but not a [singular] feature, thereby deriving the ungrammaticality of singular bare nouns in argument position (cf. *I am looking for man).

Zamparelli does not discuss how a null SD is licensed in subject position with stage-level predicates, as in (95), which admit a weak interpretation:
a. [SDP SD [PDP Many/three
b. [SDP SD [PDP Molti/tre
[KIP students]]] have
passed the exam.
[KIP studenti]]] hanno superato l'esame.

In this discussion, the English-Italian contrast arising in subject position (96), where bare nouns are not possible in Italian (see Longobardi 1994), becomes problematic especially contrasting (96b) with (95b), where weak quantifiers do not appear to undergo the same restriction. If a null SD is somehow licensed in Italian (95b) on a par with English (95a), it should also license $\mathrm{PD}_{\text {[plural] }}$ in (96b), as it does in (96c) (parallel to (94c) above), contrary to fact:

(96) a. [SDP SD [PDP $\mathrm{PD}_{\text {[plural] }}[\mathrm{KIP}$ good students]]] have passed the exam.

b. $\quad{ }^{*}\left[\mathrm{SDP} S \mathrm{SD}\right.$ [PDP $\mathrm{PD}_{\text {[plural] }}[\mathrm{KIP}$ bravi studenti]]] hanno superato l'esame.

c. Cerco [sDP $\mathrm{SD}$ [PDP PD $_{\text {[plural] [KIP }}$ bravi studenti]]]. [I] am looking for good students

An advantage of (93) is that it establishes a correlation between each layer and different types of nominal projections. SDP is the layer of nominal arguments, PDP is the layer of nominal predicates, and KIP is the layer that refers to Kinds (see (97)). This tripartition of nominal types finds confirmation in the different morphology of clitic elements in Italian: SDP is the clitic displaying Agr features such as the accusative $l o, l a, l i, l e$; PDP is the uninflected clitic lo which resumes a predicate; 
while KIP corresponds to the quantitative clitic ne (thereby predicting that ne can only be extracted from weak quantifiers) (see (98)):

(97) a. Gianni conosce [SDP questi [PDP [KIP dottori]]].

G. knows these doctors

b. Gianni è [PDP un [KIP dottore]].

G. is a doctor

c. Gianni conosce [SDP [PDP molti [KIP dottori]]].

G. knows these doctors

(98) a. Gianni li conosce [SDP li]]].

G. them knows

b. Gianni lo è [PDP $₫]$.

G. it is

c. Gianni ne conosce [SDP ne [PDP molti/tre [KIP ne]]].

G. NE knows many/tre

Note that argumental $l i$ in (98a) and predicate $l o$ in (98b) move as full projections, whereas ne is extracted from the quantified expression and therefore needs an escape hatch. This is provided by SpecSDP which is projected and void. The prediction is therefore that ne can only be extracted from weak quantifiers. This is borne out as regards strong determiners as ogni, ciascuno, and questi in (99b):

a. Gianni ha salutato [SDP ogni/ciascun/questo [PDP [KIP ragazzo]]].
G. greeted
each/every/this
boy

b. ${ }^{*}$ Gianni ne ha salutato [SDP ognuno/ciascuno/questo [PDP [KIP ne]]].

G. NE greeted each.one/every.one/this

The proposal is, however, problematic if we consider that the strong reading is possible in object position, as in (100a), where the vague numeral and the cardinal occurs with a partitive PP, and ne can freely extract, as in (100b):

(100) a. Gianni ha salutato molti/tre di quei ragazzi.

G. greeted many/three of those boys

b. Gianni ne ha salutati molti/tre di quelli.

G. NE greeted many/three of those

The sentence in (100b) should be ungrammatical, contrary to fact. When it contains molti, it should be ungrammatical because molti fills specSDP, which should thus be unavailable as an intermediate landing site for ne-extraction. When it contains tre, which fills the SD head, it should also be ungrammatical because Zamparelli $(2000,145)$ proposes that "the specifiers of a lexically filled SD ${ }^{\max }$ [SDP] cannot be used as an (intermediate) landing site" to account for the ungrammaticality of the structurally parallel *Gianni ne ha salutati $i$ molti 'Gianni NE greeted the many'.

Zamparelli's proposal predicts the co-occurrence of an element in SDP and an element in PDP, as in (2a') above, which is attributed the structure in (101a). However, it cannot account for the unacceptability of (101b), which should have the same 
structure as (101a); also see *one a man; ${ }^{*}$ each a man; ${ }^{*}$ two s'm people (where $s^{\prime} m$ is the weak form of some, which Zamparelli assumes to occur in PDP):

(101) a. [SDP these [PDP many [KIP... men]]]

b. $\quad{ }^{*}[\mathrm{SDP}$ every [PDP a [NP man]]]

To overcome this problem, Zamparelli $(2000,125)$ proposes the principle of redundancy (102) (his (333)) which rules out the insertion of two quantifiers with the same function:

(102) Two functional words $\mathrm{F}_{\mathrm{i}}, \mathrm{F}_{\mathrm{j}}$ within the same DP give an impossible representation if the meaning of $F_{i}$ entails the meaning of $F_{j}$ or vice-versa.

In (101b), every would be redundant with the weak quantifier $a$ because the universal entails the existential.

The principle in (102) is, however, too restrictive because it excludes possible combinations in English like many a $N$ seen in (65) above. Note also that while English ${ }^{*}$ one a man is correctly excluded by (102), the same combination is grammatical in Ladin $ø n a_{\mathrm{FEM}} n a_{\mathrm{FEM}}$ 'one $\mathrm{a}$ ', as in (66) above. The general principle of redundancy appears to be inadequate to capture this kind of cross-linguistic variation. Zamparelli $(2000,126)$ accommodates some of these cases under the rubric of "complex determiners," which he takes to be in SpecSDP or SpecPDP according to their interpretation, as some twenty in (81b), where some modifies twenty being synonymous to 'approximately' (while the combination ${ }^{*} t w e n t y s^{\prime} m$ is excluded by the principle of redundancy).

Finally, differently from the QP and AP proposals in (63) and (71) respectively, Zamparelli's structure (93) cannot directly derive (80) and (81a), where a quantifier precedes a strong definite determiner which in turn precedes a weak quantifier (cf. all these many children). To accommodate for this, Zamparelli assumes that all is adjoined to the Nominal Expression, as originally proposed by Sportiche (1988), therefore adjoined to SDP.

Ihsane (2008) further develops Zamparelli's layered DP hypothesis by detailing the different interpretations of the singular existential determiner un in French and assigning a different projection to each interpretation. She splits the SDP into SRefP and $\mathrm{QP}$, thus differentiating strong quantifiers from definite determiners and pronouns. She further splits PDP into PropP and NumP, thus differentiating cardinals from number features. The first merge position of the lexical item $u n$ is Num; to trigger the other interpretations, movement of $u n$ to the higher heads is assumed. The four cases are exemplified below:

(103) a. Mon fils est [NumP un petit coquin]. my son is a little rascal

b. Marie cherche [Propp un [NumP clown]]. Marie is looking for a clown

c. [PropP Un violoncelliste] a joué [QP une [PropP a cellist has played a suite aujourd'hui. today 
d. Jean n'a pas acheté [SRefP un [QP [PropP Jean not has not bought a book

Differently from Zamparelli, Ihsane assumes that the minimal structural level for arguments is PropP (property phrase). The higher levels QP and SRefP (Subject Reference phrase) are crucially projected only to trigger the relevant interpretations. The problems with the licensing of empty inactive projections do not arise. The most compelling evidence in favor of the hypothesis of different levels of projections in different types of Nominal Expressions as in (103) comes from Relativized Minimality effects in QR (quantifier raising) and quantifier scope (see Ihsane 2008 for detailed discussion; also see Quantifier Scope Ambiguities).

In a line of research according to which nominal expressions are predicate structures, ${ }^{9}$ Martí i Girbau (2010) proposes that the quantifier is a QP which starts as a predicate selecting a NP or a DP as its subject, as shown in (104):

$$
\text { [DP QP D [NumP QP NUM [KP QP F + K [FP NP/DP F QP]]]] }
$$

The functional head $F$ raises to a higher functional head $K$ which provides NP/DP with case features. This complex head is realized as de. The KP is further embedded in NumP, which is in turn embedded in DP as any other nominal expression. The QP is moved step by step to the specifiers of the above projections. The advantage of the proposal is a unified structure for all types of quantified expressions, with or without the definite determiner, with or without the partitive PP, and all types of quantity items, including uninflected força 'quite a lot', quantity nouns as in un munt 'a pile', and complex determiners like uns quaranta 'approximately forty'. Quantifiers are specified in the lexicon for the NP or DP category of their argument. Cases like many boys are obtained when NP is selected, while many of the boys is obtained by selecting a DP. Quantifiers like mults 'many' and cardinals have the double option, while other quantifiers such as força and poques 'few' lack the DP option.

\subsection{Conclusions}

In section 2, we have presented an overview of the major trends of research on the syntax of quantified expressions in generative grammar. The studies presented so far have deepened the insight into the upper portion of the quantified structure. In what follows, we will focus on the lower portion of the quantified expression which contains the lexical content.

\section{Partitive phrases}

In this section we distinguish a "genuine" partitive PP, which occurs with existential and distributive quantifiers, from other of-PPs that induce a "kind" interpretation and a "collective" interpretation. We also show that in some cases, partitive PPs are headed by other prepositions, which are lexically partitive and do not need to co-occur with a quantifier to induce the partitive interpretation. 


\subsection{The "genuine" partitive PP}

In this section, we address the question in (11b). "Do the sentences in (1) and (6), repeated here as (105), have the same structure or different structures?"

(105) a. three/many [boys]

b. three/many [of the boys]

As observed in section 2.1.2, in the late 1970s it was already noted that the quantitative phrase boys in (105a) and the partitive phrase of the boys in (105b) are different constituents. They behave differently with respect to movements of various kinds (see (20), (22), (23)), cannot be coordinated (24), and have different semantics (26); furthermore, only the presence of the partitive PP is bound to the presence of a quantifier.

Abney (1987) suggests that the PP is the complement of the quantified $\mathrm{N}$ (also see Boivin 2005, fn. 13). However, in (48)-(50) above we have already seen evidence against the idea that the partitive PP is part of the quantitative phrase (as a complement or an immediate modifier of $\mathrm{N}$ ). Similar evidence can be constructed on the basis of Italian left-dislocation (also see Left Dislocation). While the complement of a noun must be dislocated together with the noun (106a) and cannot be stranded (106b), ${ }^{10}$ a partitive PP must be left in situ when the noun phrase is dislocated (107b) versus (107c). This suggests that the partitive PP is not a complement of $\mathrm{N}:^{11}$

(106) a. Di studenti in medicina, ne conosco due. of students in medicine, [I] NE know two

b. * Di studenti ne conosco due in medicina. of students [I] NE know two in medicine

(107) a. Ho visto due studenti di quelli del tuo corso.

[I] have seen two students of those of-the your class

b. ${ }^{*} \mathrm{Di}$ studenti di quelli del tuo corso ne ho visti due ne.

of students of those of-the your course [I] NE have seen two

c. Di studenti, ne ho visti due ne di quelli del tuo corso.

of students [I] NE have seen two of those of-the your class

It is also doubtful that the partitive PP is (optionally) adjoined to the quantitative phrase. At least in Italian, the partitive PP is unable to appear with any other type of nominal expression. As shown in (108), it cannot occur with definite or universally quantified expressions:

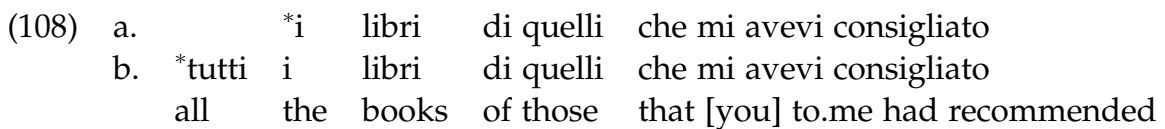

Parallel to the French examples in (33) and (34) above, Cardinaletti and Giusti (1992) argue for Italian that the two phrases are not mutually exclusive, but can co-occur, as in (109): 
(109) a. Ho letto molti libri di quelli che mi avevi consigliato.

[I] have read many books of those that [you] to.me had recommended

b. Ne ho letti molti [ne] di quelli che mi avevi consigliato.

[I] NE have read many of those that [you] to.me had recommended

c. Ho letto molti [e] dei libri che mi avevi consigliato.

[I] have read many of the books that [you] to.me had recommended

This is the stance taken in much literature, with great differences as regards the category of the quantitative phrase (which will be the topic of sections 4-5) and the structural relation between the quantitative phrase and the partitive phrase, which is discussed in this section.

Zamparelli (1998, 273) proposes the structure in (110), where the projection RP (Residue Phrase) is complement to PD (see structure (93) above): its head is filled by the preposition of and its specifier hosts a copy of the KIP embedded in the lower SDP:

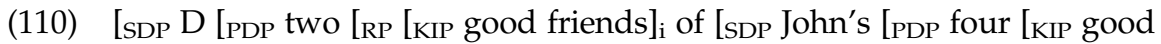
friends $\left.\left.\left.\left.\left.]_{i}\right]\right]\right]\right]\right]$.

The proposal unifies a number of apparently unrelated phenomena, namely partitive PPs occurring with quantifiers, possessive constructions like two friends of John's, and the kind constructions an animal of that kind and that kind of animal.

The proposal also captures the identity between the intension of the partitive $\mathrm{PP}$ and that of the quantitative phrase, by proposing that they are one and the same element, namely KIP which is copied as SpecRP. Another advantage of the RP-proposal is that it allows Zamparelli to motivate the ungrammaticality of a partitive PP with a weak quantifier preceded by a (strong) definite determiner, as in *these three of the boys (also see (91) above), along the following line. The insertion of the RP projection introduces an operator that maps a plurality into the set of all its proper subparts, except its maximal member (supremum). This $\mathrm{RP}$ is incompatible with a definite determiner which picks out such a maximal element.

Given that a partitive phrase induces a strong reading of the quantified expression (as witnessed by their ungrammaticality in existential sentences (cf. *There are some of the children in the garden)), insertion of RP would be expected to force whatever quantifier is in PD or SpecPDP to move to SD or SpecSDP, respectively, as strong quantifiers should have a filled SDP. It is, however, not clear what should force such movement, as RP is lower than PDP.

A completely different perspective is represented by approaches that claim that quantified expressions only contain a single NP, namely the one inside the partitive phrase (see Corblin 1990; Battye 1987; Kupferman 1999, 2004; Lopez 2000; Martí i Girbau 1999; 2010). The most compelling argument is provided by the quantified expressions containing a personal pronoun, such as Catalan tres de noaltres, English three of us. According to Martí i Girbau (2010,29-30), if a parallel is made between pronouns and demonstratives, we would expect to have the same distribution of the overt $\mathrm{N}$ in (111a) and (111b), contrary to fact. With pronouns 
used as determiners, the only possible occurrence of the overt $\mathrm{N}$ is in the partitive $\mathrm{PP}, \mathrm{as}$ in (111c):

(111) a. two [NP linguists] of those $[\mathrm{NP} e] \ldots$

b. "two [NP linguists] of us/them [NP $e$ ]

c. two [NP $e$ ] of us [NP linguists]

A second argument is provided by the impossibility of having an adjectival modifier preceding a true partitive PP, as in (112b). The contrasts in Catalan (112) are explained by Martí i Girbau (2010, $149 \mathrm{ff}$.) with the claim that the quantitative phrase and the true partitive PP are in complementary distribution. In (112a) the PP is not a true partitive; in (112c) the stranded modifier shows that the null quantitative phrase is present and this is so, because the partitive PP is missing:

(112) a. He llegit una novel · la [molt divertida] de les quatre que em vas deixar. [I] have read a novel very amusing of the four that [you] to.me lent

b. *He llegit una [de molt divertida] de les quatre novel · les que em vas deixar.

c. He llegit dues novel · les avorrides i una [e] de molt divertida. [I] have read two novels boring and one of very amusing

The data in (111)-(112) can be accommodated in the approaches that assume the possibility of co-occurrence of quantitative and partitive phrases with further assumptions on the level of attachment of what can be left stranded when the quantitative phrase is null and on how a null quantitative phrase is interpreted in the presence of the partitive PP (see section 3.4 and section 5 for discussion).

Finally note that both Cardinaletti and Giusti (1992; 2006) and Martí i Girbau $(1999 ; 2010)$ suggest that the partitive PP is selected by the quantifier. The crucial difference between the two accounts is that while Cardinaletti and Giusti claim that the partitive PP always co-occurs with a quantitative phrase, Martí i Girbau claims that the partitive PP is in complementary distribution with it.

\subsection{The adjunct partitive PP}

The "genuine" partitive PP must be differentiated from an optional, adjunct PP which is preferably introduced by the preposition tra/fra 'among', as shown in Italian (113). Cardinaletti and Giusti (1992; 2006) call it "adjunct partitive," because it is not selected by an existential quantifier and it is compatible with any kinds of nominal expressions, including definite expressions and universal quantifiers:

(113) a. Ho letto solo questi libri di linguistica tra/fra quelli che

[I] read only these books of linguistics among those that [you]

mi avevi consigliato.

to.me had recommended

b. Tutti i libri di linguistica tra/fra quelli che mi avevi

all the books of linguistics among those that [you] to.me had

consigliato mi sono piaciuti.

recommended to.me pleased 
c. Ho letto (i) molti libri di linguistica tra/fra quelli che mi avevi consigliato. [I] have read (the) many books of linguistics among those that [you] to.me had recommended

In sentence-initial position, in Italian, the adjunct partitive PP can also be introduced by $d i$ :
$\begin{array}{ll}\text { a. Tra/Fra i libri di linguistica, } & \text { ho letto } \\ \text { among the books of linguistics, } & {[\mathrm{I}] \text { have }}\end{array}$ quelli che mi avevi consigliato. had recommended
b. Di (quei) libri, ho letto solo questi. of (those) books [I] have read only these

Note that (114b) is no counterevidence to the claim that a "genuine" partitive cannot be associated to a definite nominal. In fact the left-dislocated di-PP can co-occur with the selected partitive PP, which confirms that the two are different kinds of constituents (115):

(115) a. Fra i libri di storia in programma, ne ho letti [molti ne [dei tuoi]]. among the books of history in the syllabus, [I] NE have read many of yours

b. Dei libri di storia in programma, ne ho letti [molti ne [dei tuoi]]. of the books of history in the syllabus, [I] NE have read many of yours

When the adjunct partitive PP is in place, it follows the selected partitive PP (116), and can only be introduced by tra/fra and not by di:

(116) a. Ho letto molti libri di storia [dei tuoi] [tra quelli in programma].

[I] have read many books of history of yours, among those in the syllabus

b. ${ }^{*}$ Ho letto molti libri di storia [dei tuoi][di quelli in programma].

The adjunct partitive does not obey the non-distinctness requirement, as will be presented in section 3.4 below. These data are confirmed for Spanish entre and Catalan d'entre discussed at length by Martí i Girbau (2010, 178-199).

\subsection{The "kind" PP}

In Italian, definite and universally quantified DPs can sometimes co-occur with a PP introduced by $d i$, as in (117a), on a par with existentially quantified DPs, as in $(117 b)$ :

(117) a. Mi piacciono (tutti) i libri [di quelli che si leggono velocemente]. to.me please all the books of those that can be read quickly 'I like the books that can be read quickly.'

b. Ho comprato dieci libri [di quelli che si leggono velocemente]. [I] have bought ten books of those that can be read quickly 
The PP introduced by di in (117) differs from the PP introduced by the same preposition in (108a) in that it does not get a partitive, but a "qualitative" or "kind" interpretation. (117a) can be paraphrased as follows: Mi piacciono (tutti) i libri del tipo che si legge velocemente 'I like (all) the books of the type that can be read quickly'. This PP can be analyzed as a modifier of the noun libri and is not related to the QP. There are empirical reasons to believe this. The "kind" PP cannot be left-dislocated on its own (118a), but only together with the DP (118b) (see (106) above). In this respect, it crucially differs from the selected partitive PP in (119) and (107b):
a. $\quad$ [Di quelli che si leggono velocemente] of those that can be read quickly
b. [Libri di quelli che si leggono velocemente] books of those that can be read quickly

ne ho comprati dieci. [I] NE have bought ten ne ho comprati dieci. [I] NE have bought ten
a. [Di quelli che mi hai consigliato tu]
ne ho comprati dieci. of those that you advised to me
[I] NE have bought ten
b. ${ }^{*}$ [Libri di quelli che mi hai consigliato tu]
ne ho comprati dieci.

This "kind" PP, which contains a kind-denoting plural, is also found in the English expression many of them, in contexts like (120a) (from Cresti 2003, 83), and differs from the partitive PP in the homophonous many of them in (120b):

(120) a. Late homework assignments are impossible to grade, and there are many of them.

b. I bought a hundred books, and I have read many of them.

Zamparelli's KIP is designed to unify this "kind" PP with the partitive PP. The data discussed in this section cast some doubts on the advantages of unifying the "kind" and the "genuine" partitive interpretation.

\subsection{The non-distinctness requirement}

As noted by Milner (1978) for French and Cardinaletti and Giusti $(1992,134)$ for Italian, the selected partitive PP and the quantitative DP must contain the same lexical noun. In fact, in Italian, while (121a) is marginal, due to the redundancy of the information conveyed, (121b) is ungrammatical, even if it is not redundant, and clearly contrasts with the synonymous (122), which contains an adjunct partitive PP:
a. Ho letto
molti libri dei libri della biblioteca.
[I] have read
many books of the books in the library
b. ${ }^{*}$ Ho letto
molti romanzi
dei libri della biblioteca.
[I] have read
many novels
of the books in the library
a. Ho letto
molti romanzi
tra i libri della biblioteca.
[I] have read many novels
among the books of-the library
b. Dei/Tra i libri della biblioteca,
ho letto
molti romanzi.
of/among the books of-the library,
[I] have read
many novels 
Cardinaletti and Giusti (2006) call this property "the non-distinctness requirement." As seen above in (110), Zamparelli (1998) highlights the fact that the entire intension projected as KIP is involved, including adnominal adjectives.

This property makes it possible to sharpen the notion of partitive PP and distinguish it from different types of PPs headed by of (also see Martí i Girbau's "false partitives"). The PPs in (123) cannot be analyzed as "genuine" partitive PPs, pace Milner $(1978,124)$. Rather, they must be analyzed as some sort of "collective" PPs, also compatible with definite and universally quantified expressions (124) (see also some/the students in the class and the like). This is shown for French in (123a) and (124a), for Italian in (123b) and (124b), and for English in (123c) and $(124 \mathrm{c})$ :

(123) a. deux livres de ta collection

b. due libri della tua collezione

c. two books of your collection

(124) a. les livres de ta collection

b. i libri della tua collezione

c. the books of your collection

Note that while the quantitative phrase and the partitive PP must have the same intension, the functional structure realizing their extension can differ. As the Italian data in (125) show, the quantifier does not agree for Number (125a)-(125b) or Person $(125 \mathrm{c})$ with the noun phrase embedded under the partitive PP: ${ }^{12}$
a. Una
[e] delle
ragazze
è arrivata.
one.F.SG
of-the girls
AUX arrived.F.SG
b. Uno
[e] $\mathrm{di}$
noi
è arrivato.
one.M.SG
us
c. Molti
of
$\begin{array}{lll}{[e]} & \text { di noi } \\ \text { of } & \text { us }\end{array}$
many
AUX arrived.M.SG
sono arrivati.
AUX arrived.M.PL

Number and Person are syntactic features that are structurally realized as functional heads external to the lexical NP (Ritter 1991). Semantically, they regard the extension of the Nominal Expression. The extension must differ if the quantitative phrase is count singular (125a) (in fact the partitive PP must be plural) or when the partitive PP has first- or second-person features (125b)-(125c) (in fact the quantitative DP, being indefinite, must have third-person features). Note that the whole quantified expression in (125) has the features of the quantitative DP (third person). The verb never agrees with the plural DP inside the partitive PP, as shown by the ungrammaticality of (126) in Italian:
a. *Una
[e] delle
ragazze
sono
arrivate.
one.F.SG
of-the
girls
AUX.3PL
arrived
b. *Uno
[e] di noi
one.M.SG
us
siamo
arrivati.
c. ${ }^{*}$ Molti
[e] di
noi
AUX.1PL
arrived
us
siamo
arrivati.
AUX.1PL arrived 
The point is most apparent with a distributive quantifier whose quantitative phrase must be singular, while the partitive PP must be plural, as usual. In Italian the quantitative phrase is overt and its third-person singular features agree with the quantifier and with the verb, as in (127a). In (127b)-(127c), the quantitative phrase is covert and the partitive PP is realized, but the quantifier and the verb still agree with the non-overt quantitative phrase:
a. Ciascuna ragazza
each.F.SG girl
b. Ciascuna $[e]$
each.F.SG
c. Ciascuna $[e]$
each.F.SG

$\begin{array}{ll}\text { delle } & \text { ragazze } \\ \text { of-the } & \text { girls } \\ \text { di } & \text { noi } \\ \text { of } & \text { us }\end{array}$

$\begin{array}{ll}\text { lavora/ } & \text { *lavorano. } \\ \text { works/ } & \text { work.3PL } \\ \text { lavora/ } & \text { *lavorano. } \\ \text { works/ } & \text { work.3PL } \\ \text { lavora/ } & \text { *lavoriamo. } \\ \text { works/ } & \text { work.1PL }\end{array}$

The quantitative phrase selected by a universal quantifier like tutti can have firstand second-person features and can do so even when it is non-overt, as in Italian (128). The first- and second-person features of the null element are identified by verbal agreement. Note that the quantitative phrase in the complement of entrambi in (128b) can have Person features, even if - for reasons we cannot discuss here - the overt pronoun is not acceptable: ${ }^{13}$
a. Tutti/Tutte (noi/voi) all.M/all.F
abbiamo/avete un sogno.
b. Entrambi/Entrambe (?*noi/voi) both.M/both.F have.1PL/2PL a dream
abbiamo/avete un sogno.
have.1PL/2PL a dream

Note finally that in Italian, when $n e$ is present, the partitive PP can only contain a pronoun (a pronominal demonstrative, such as quelli in (129a) and questi in (129b), a focused personal pronoun such as loro in (129c), or a relative pronoun such as cui in (129d); also see French (34b) and (34c) above) and cannot contain a referential expression (130): ${ }^{14}$
a. Ne ho
molti [ne]
[I] NE have
read
many
letti
di quelli (che mi hai consigliato).
b. Ne ho
letti
molti [ne]
[I] NE have
read
many
molti [ne]
c. Ne ho
visti
many
[I] NE have
seen
ne ho letti
molti [ne]
of those (that [you] to.me have
recommended)
d. Quei libri di di cui
linguistica,
di questi qui.
of these here
those books
of linguistics,
of which
read many
di LORO, non di voi.
of them, not of you
[dicui], erano piuttosto
interessanti.
were very interesting

(130)
a. ${ }^{*} \mathrm{Ne}$ ho
letti
b. ${ }^{*} \mathrm{Ne}$ ho
letti
molti [ne]
[I] NE have
read many

dei libri (che mi hai consigliato).

di quei libri (che mi hai consigliato).

of-the/ of those books (that [you] to.me have advised) 
The ungrammaticality of (130) is immediately captured by those approaches that exclude the co-occurrence of the quantitative and partitive phrase, with the corollary assumption that in (129), the PP headed by $d i$ is not an instance of the "genuine" partitive PP. In approaches which take the two phrases to co-occur, (130) is ungrammatical because the pronoun refers back to a previously mentioned nominal expression. The empty quantitative phrase is thus interpreted on the basis of such antecedent and not on the basis of the DP inside the partitive PP, as in the cases in which the quantitative clitic is not present (see (191) below).

\subsection{Universal quantifiers and partitive PPs}

We have observed above that the "genuine" partitive PP is different from other PPs with of or with other prepositions, which can occur with any kind of nominal expression and in left-dislocated position.

The partitive PP refers to the set out of which the quantifier picks up its restrictor, which is a subset of it (see Cresti 2003, 83). For universal quantifiers, the set and the restrictor have the same extension, and this is why in Italian, no partitive PP is selected by universal tutti in (108b), tutte in (131a), universal entrambi in (131a), and the coordinated Q tutte e due 'all and two' in (131b), which can only take a definite DP:

a. Tutte/Entrambe (*del)le ragazze sono arrivate. all/both of the girls have arrived

b. Tutte e due (*del)le ragazze sono arrivate. all and two of the girls have arrived

As is clear from the gloss of (131a), things are different in English. There are two ways of interpreting the contrast between Italian and English: one can attribute different (unpredictable) selectional properties to quantifiers across languages, or one can propose that an of phrase in English is ambiguous between the "genuine" partitive PP and the adjunct partitive PP (often introduced by tra/fra but also introduced by $d i$ in Italian left-dislocation constructions (114b) and (115b)).

The fact that of in English can occur with universal quantifiers both/all (of) the girls correlates with other uses of of which are different from "genuine" partitive PP. For instance, Cresti $(2003, \mathrm{fn} .11)$ points out a possible reading of English many of them where of them has the same interpretation as Italian quantitative ne:

a. John has few friends, but Mary has many of them.

b. Gianni ha pochi amici, mentre Maria ne ha molti.

Doetjes $(1997,159)$ takes the opposite stand and claims that the partitive PP is possible with all quantifiers, and that the exception is represented by languages that pattern with Italian (131) above, such as French and Dutch. 


\section{The syntax of quantitative clitics}

In this section, we focus on quantitative clitics like Italian ne. As we have done above with the structure of quantified expressions, we start with a presentation of various proposals that have been put forth in the literature. First, we present the general properties of quantitative clitics. Then, we address the question whether ne is a non-maximal $\left(\mathrm{N}^{\prime}\right)$ or a maximal category. In the latter perspective, four competing analyses are considered: (i) the quantitative clitic stands for the partitive PP due to the genitive morphology that they share; (ii) it stands for a quantitative phrase which is a full extended nominal projection, therefore of category DP; (iii) it is an incomplete extended projection corresponding to the intension (kind) KIP; (iv) it is even smaller - that is, NP.

\subsection{General properties}

Quantitative clitics only occur with existential quantifiers and are ungrammatical with distributive and universal quantifiers, as exemplified with Italian in (133), (134), and (135) respectively:
a. Ho visto molti/tre [Ø ragazzi].
[I] have seen many/three boys
b. Ne ho visti molti/tre [ne].
[I] NE have seen many/three
c. Ne ho visti molti/tre [ne] di quelli.
[I] NE have seen many/three of those
(134) a. Ho visto ogni/ciascun [Ø ragazzo].
[I] have seen each boy
b. ${ }^{*}$ Ne ho visto ogni/ognuno/ciascun/ciascuno.
[I] NE have seen each

(135) a. Ho visto tutti/entrambi [i ragazzi].

[I] have seen all/both the boys

b. ${ }^{*} \mathrm{Ne}$ ho visti tutti/entrambi [ne].

[I] NE have seen all/both

Zamparelli $(2000,134)$ captures the facts in (133)-(135), stating that ne only occurs with weak quantifiers. This explains the ungrammaticality of (134b) and (135b) in a unified way: distributional and universal quantifiers are strong quantifiers; they are therefore in SDP and block ne-extraction. However, this account predicts ne-extraction to be blocked when a partitive PP occurs (if the partitive PP forces the strong reading; see above), contrary to fact (133c).

Cardinaletti and Giusti $(1992 ; 2006)$ also propose that clitic extraction takes place through the highest specifier of the quantity expression, but derive the facts in (133)-(135) through an independent subclassification of quantifiers which 
takes their case and structural properties into account. They divide quantifiers in partitive case assigners (existential and distributive) and case-transparent (universal). ${ }^{15}$ Existential quantifiers, such as cardinals, vague numerals, and alcuni, as in (133), assign partitive case and provide an escape hatch for ne-cliticization. ${ }^{16}$ Distributive quantifiers, such as ogni and ciascun(o) in (134b), assign partitive case (witnessed by the $-u n(o)$ form of the pronominalizer, see (31) above), but do not allow ne-extraction because their highest specifier is filled by a distributive operator which triggers the universal interpretation despite the singular number of the restrictor. Universal quantifiers, such as tutti and entrambi in (135), are case-transparent: they do not assign partitive case to their complement and therefore co-occur with quantitative ne. They provide an escape hatch for the movement of accusative clitics (see (58) above), of genitive ne (as in (Di Maria) ne conosco tutti $i$ difetti '(of Mary) I NE know all the faults'), and of full DPs in floating constructions (see (51) and Gli studenti sono arrivati tutti 'the students have arrived all').

This hypothesis captures the fact that the quantitative phrase occurs with the preposition di/de in a number of contexts: (i) when the quantifier is invariable and does not agree with the quantitative phrase, as in French beaucoup (136a), like peu, and combien, and unlike agreeing plusieurs (136b) (see Martí i Girbau 1995 for Catalan), (ii) when the quantitative phrase is left- or right-dislocated, as in French (137) and Italian (138), (iii) when the quantifier is non-overt as in Italian (139b) versus (139a):

$$
\begin{aligned}
& \text { a. J'ai vu beaucoup *(de) filles. } \\
& \text { I have seen many of girls } \\
& \text { b. J'ai vu plusieurs }\left({ }^{*}\right. \text { de) filles. } \\
& \text { I have seen many of girls }
\end{aligned}
$$
a. De filles, j'en ai vu plusieurs.
b. J'en ai vu plusieurs, de filles.
[I] NE have seen many of girls
a. Di ragazzi, ne ho
visti molti.
b. Ne ho visti molti, di ragazzi.
of boys, [I] NE have seen many of boys
a. Ne conosco due [ne] (di) simpatici.
[I] NE know two of nice
b. Ne conosco $\varnothing\left[\right.$ ne] ${ }^{*}($ di) simpatici.
[I] NE know [some] of nice

Assuming that the partitive case assigned by a quantifier is incompatible with other case assignments (pace Belletti 1988), this hypothesis also captures the fact that full DPs can extract to move to subject position (where nominative case is assigned) only when embedded by universal quantifiers, which are case-transparent: compare *Studenti sono arrivati tre 'Students arrived three' versus Gli studenti sono arrivati tutti $e$ tre 'The students arrived all and three'. 


\subsection{Quantitative clitics as $\mathrm{N}^{\prime}$}

Ruwet $(1972,49-50)$ and Milner $(1978,49)$ are the first authors who differentiate quantitative en from prepositional en in French. Quantitative en cannot be extracted out of a quantified expression occurring in subject position, while this is possible for genitive en (see Haïk 1982; Pollock 1986):
a. Deux/Beaucoup de cheminées sont penchées. two/many of chimneys are leaning
b. ${ }^{*}$ Deux $/{ }^{*}$ Beaucoup en sont penchées.
a. La cheminée de l'usine est penchée. the chimney of the factory is leaning
b. La cheminée en est penchée.

In French, quantitative en can apparently resume both a definite and an indefinite noun phrase, while genitive en can only pronominalize a definite noun phrase (Milner 1978, 49-50).
a. Les/Des livres de Zola, j'en ai lu deux [en]. the/some books by Zola I EN have read two
b. Ce/*Un livre de Zola, j'en ai lu la fin [en] avec plaisir. this/a book by Zola I EN have read the end with pleasure

On the basis of the differences between quantitative and genitive en, Milner (1978) suggests that the former is an $\mathrm{N}^{\prime}$, while the latter is a maximal projection ( $\left.\mathrm{N}^{\prime \prime}\right)$. Assuming a Simple Noun Phrase Hypothesis as in Selkirk (1977), Belletti and Rizzi (1981) also treat Italian ne as an $\mathrm{N}^{\prime}$ (see section 2.2). Ne pronominalizes the head noun and its complements, while the quantifier (assumed to be in SpecNP) remains in place:
a. Maria conosce tre racconti del nonno.
Maria knows three stories of grandpa
b. Maria ne conosce tre [ne].
Maria NE knows three

A second argument for the $\mathrm{N}^{\prime}$-status of Italian ne discussed by Rizzi (1979) was already presented in (29)-(30) above. Assuming a structure where prenominal APs are under $\mathrm{N}^{\prime}$ and postnominal APs are under $\mathrm{N}^{\prime \prime}$, Rizzi shows that prenominal adjectives cannot be stranded by ne cliticization, as shown by the contrast in (144):
a. Ho letto
[NP un [N $_{\mathrm{N}^{\prime}}$ lunghissimo
[I] have read
INe un IN
$\left[\mathrm{N}^{\prime}\right.$
[N libro]]].
b. Ho letto lNP un $\left\lfloor_{N^{\prime \prime}}\right.$ [N,lunghissim book
c. ${ }^{*} \mathrm{Ne}$ ho letto
[NP un
d. Ne ho letto [NP uno $\left[_{N^{\prime \prime}}\left[_{N^{\prime}}\right.\right.$ ne
[N libro]] lunghissimo]].
lunghissimo]].

In (144c) the adjective must be analyzed as prenominal due to the reduced form $u n$ of the quantifier, parallel to (144a). In (144d), the adjective must be analyzed as 
postnominal, since the quantifier displays the full form uno, which also appears when the quantifier is bare, as in Ne ho letto uno '[I] NE have read one'. According to Rizzi, the contrast between (144c) and (144d) can be explained by assuming that $n e$ is an $\mathrm{N}^{\prime}$ and that only elements that are external to $\mathrm{N}^{\prime}$ can be left in place by necliticization.

Rizzi's observations are confirmed by the behavior of other kinds of adjectives in Italian. This is most apparent in the case of adjectives such as mero in (145) and certo in (146). Mero can only appear prenominally and is ungrammatical when ne-cliticization applies. Certo has a different interpretation according to the position it occupies; in the ne-construction, it only has the postnominal interpretation:
a. Si è fatta una mera illusione. [she] had a mere illusion
b. *Si è fatta una illusione mera.
c. *Se ne è fatta una [ne] mera.
a. Hanno dato una certa notizia. [they] have given a certain (= particular) piece of news
b. Hanno dato una notizia certa. [they] have given a piece of news certain (= sure)
c. Ne hanno data una [ne] certa. [they] NE have given one certain (= sure)

However, the $\mathrm{N}^{\prime}$-analysis of ne is not without problems. On the theoretical level, ne would represent the only instance of $X^{\prime}$-movement. On the empirical level, this analysis encounters problems when different classes of modifiers and arguments of the noun are taken into account. As noted by Cinque (1991, 122), postnominal adjectives like principale in Italian cannot be stranded by ne-cliticization. The ungrammaticality of (147c) is unexpected in Rizzi's analysis, unless we assume that principale, contrary to other postnominal adjectives, is generated under $\mathrm{N}^{\prime}$ :
a. Gianni ha due ragioni principali per non accettare quel posto. Gianni has two reasons main to not accept that position
b. *Gianni ha due principali ragioni per non accettare quel posto.
c. ${ }^{*}$ Di ragioni, Gianni ne ha due [ne] principali per non accettare of reasons Gianni NE has two main to not accept quel posto. that position

Another problem for the $\mathrm{N}^{\prime}$-analysis of Italian ne is represented by the arguments of the noun that can be left in situ under ne-cliticization. In addition to (143b) and (148), where ne stands for both the head noun and its complement, the sentences in (149) are also possible:
a. Di ritratti di mio nonno,
ne possiedo
due [ne].
b. Di ritratti di Picasso, ne possiedo
c. Di ritratti di quel collezionista, ne possiedo due [ne]. of pictures of my grandpa/Picasso/that collectionist 
(149) a. Di ritratti, ne possiedo due [ne] di mio nonno.

b. Di ritratti, ne possiedo due [ne] di Picasso.

c. Di ritratti, ne possiedo due [ne] di quel collezionista.

of pictures [I] NE have two of my grandpa/Picasso/that

collectionist

In Giorgi and Longobardi's (1991) analysis, the arguments of the noun occupy different structural positions inside the NP depending on their theta role:

(150) $\left[\mathrm{NP}_{\mathrm{N}}\left[\mathrm{N}^{\prime \prime \prime}\left[\mathrm{N}^{\prime \prime}\left[\mathrm{N}^{\prime} \mathrm{N}\right.\right.\right.\right.$ internal argument] agent $]$ possessor $\left.]\right]$

The apparent possibility of leaving any argument of the noun stranded could lead one to the assumption that ne can resume any projection of $\mathrm{N}$, from $\mathrm{N}^{\circ}$ to $\mathrm{N}^{\prime \prime \prime}$. It is theoretically undesirable that a lexical item stands for different projection levels. More seriously, the fact that ne can stand for the head noun in (149a) mars the argument built on the non-occurrence of prenominal adjectives with ne, seen above in (144), (145), and (146).

Both problems can be solved by assuming that the quantitative clitic pronoun ne, like other clitic pronouns, binds a maximal projection. This proposal is a natural consequence of the hypothesis that quantified expressions are QPs that embed a maximal projection. The cases in which ne seems to bind an intermediate projection of $\mathrm{N}$ must be analyzed otherwise. This issue is addressed in section 4.3.

\subsection{Quantitative clitics as maximal projections}

Cinque (1991) and Cardinaletti and Giusti (1992) suggest that in Italian, the material left in place by ne-cliticization is a modifier of the noun phrase, occurring in a postnominal predicative position. Among adjectives, only those that can occur in predicative position (as in (151)-(152)) can appear in ne-constructions (cf. (145)(146) above):
a. ${ }^{*}$ Questa illusione è mera. this illusion is mere
$\begin{array}{lll}\text { b. } & \text { *itengo questa illusione } & \text { mera. } \\ \text { [I] consider this illusion } & \text { mere }\end{array}$

(152) a. Questa notizia è certa.

this piece of news is certain (= sure)

b. Ritengo questa notizia certa.

[I] consider this piece of news certain (= sure)

This solves the paradox built by the data with the Italian adjective principale. Since it cannot appear in predicative constructions, as shown in (153), it is expected that it cannot occur with ne, as shown in (147c):

(153) a. $\quad{ }^{*}$ Le due ragioni di Gianni the two reasons of Gianni per non accettare quel posto not to accept that position sono principali. are main 


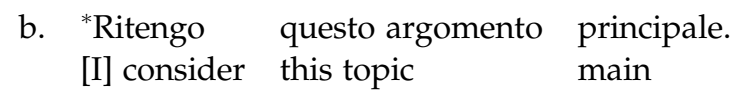

The same proposal should be made for the apparent arguments of the noun in (149) above. They must be considered modifiers of the noun, occurring in the postnominal predicative position. The prediction that they also enter predicative constructions is borne out, as exemplified for Italian in (154):
a. Quel ritratto è di mio nonno.
b. Quel ritratto è di Picasso.
c. Quel ritratto è di quel collezionista.
that portrait is of my grandpa/Picasso/that collectionist

The complements that cannot occur as predicates (155) are also ungrammatical with ne (156), as noted by Cinque (1991, 121-122) for Italian:
a. *Quello studioso è del Petrarca. that scholar is of Petrarch
b. *Quell'esperto è in microprocessori. that expert is in microprocessors
c. *Quel ladro era di galline. that thief was of chickens
a. ${ }^{*}$ Di studiosi, ne stimano anche uno del Petrarca. of scholars [they] NE estimate also one of Petrarch
b. *Di esperti, ne hanno assunto uno in microprocessori. of expertes [they] NE have hired one in microprocessors
c. *Di ladri, ne hanno preso uno di galline. of thieves [they] NE have caught one of chickens

Cardinaletti and Giusti (1992) also show that in Italian, a complement clause like di risolvere il problema in (157a) cannot appear as a predicate (157b) and cannot be stranded by $n e$ cliticization (see (157c) vs. (157d)): ${ }^{17}$

(157) a. Ci sono due modi di risolvere il problema. there are two ways to solve the problem

b. *Questo modo è di risolvere il problema. this way is to solve the problem

c. *Di modi, ce ne sono due di risolvere il problema.

d. Di modi di risolvere il problema, ce ne sono due. of ways to solve the problem there NE are two

In conclusion, even in an EST perspective, there are reasons to believe that quantitative clitics bind a maximal projection and not a $N^{\prime}$. In more recent terms, this means that the maximal projection is not "minimal" but includes functional structure. In what follows, we provide an overview of different possible analyses of the maximal projection given in the literature. 


\subsection{The category of quantitative clitics}

\subsubsection{Quantitative clitics as PPs}

Unlike Ruwet (1972) and Milner (1978) (see section 4.2), Kayne (1975) takes French quantitative $e n$ to be a prepositional clitic. The argument for this proposal is the fact that en, contrary to the nominal object clitics le/la/les and parallel to prepositional clitics, is invariable, as shown in (158), and does not trigger past participle agreement (also see Comparative Deletion and Comparative Subdeletion), as shown in (159): ${ }^{18}$
a. Elle le/la/les voit. she him/her/them sees
b. Il en parle tout le temps, de sa maison/de son travail/ he EN speaks all the time of his house/of his work/ de ses problèmes. of his problems
c. Paul a deux sœurs/frères; j'en ai trois.
Paul has two sisters/brothers; I EN have three
(159) a. On l' a mise sur la table (la fourchette). one it has put.F.SG on the table the fork
b. Il en a parlé( $\left({ }^{*} \mathrm{e}\right)$ tout le temps, de sa maison. he EN has spoken (*F.SG) all the time of his house
c. ${ }^{*}$ On en a mises sur la table (des fourchettes). one EN has put.F.PL on the table some forks
d. On en a mis sur la table (des fourchettes).

Assuming that quantified expressions have the underlying form deux de sours, Kayne (1975) suggests that quantitative en pronominalizes the complement de sœurs, or more precisely, its pronominal counterpart de elles. ${ }^{19}$

Belletti (1979, sect. 5.3) assumes a similar analysis for Italian ne. Ne stands for the partitive phrase introduced by $d i$. The proposal that ne is a prepositional clitic has the advantage of unifying quantitative ne with the non-quantitative instances of ne, which stand for PPs introduced by di (160) or $d a$ (161). These PPs can be complements to verbs, nouns, and prepositions:

(160) a. Ne ho parlato. (ne = del progetto)

[I] NE have spoken (NE= of-the project)

b. Ne ho comprato un ritratto. (ne = della regina)

[I] NE have bought a picture ( $\mathrm{NE}=$ of-the queen)

c. Ne sono rimasto senza. (ne= sigarette)

[I] NE am left without $\quad(\mathrm{NE}=$ cigarettes $)$

(161) a. Ne uscì un uomo. (ne = dalla casa)

NE came out a man $\quad(\mathrm{NE}=$ from-the house $)$

b. Ne era riamato. (ne $=$ da lei/lui)

NE was loved back (NE = by her $/$ him $)$

c. Ne sono finalmente fuori. (ne=da questo incubo)

[I] NE am finally out $\quad(\mathrm{NE}=$ of this nightmare) 
Like French quantitative en, Italian quantitative ne is invariable, therefore different from accusative clitics (162a) and similar to prepositional ne (162b) in that it is not specified for gender (162c), or number (163): ${ }^{20}$
a. Paolo lo/la/li/le
detesta.
Paolo him/her/themF/themM hates
b. Ne parla sempre, della sua casa/del suo lavoro/dei suoi problemi/ [he] NE speaks always of his house/of his work/of his problems/ delle sue amiche. of his girlfriends

c. Paolo ha due sorelle/fratelli; io ne ho tre.

Paolo has two sisters/brothers I NE have three
a. Di libro, ne ho letto uno.
of book [I] NE have read one
b. Di libri, ne ho letti due.
of books [I] NE have read two

Lack of number and gender on quantitative ne may suggest that its basic position is the partitive PP. But we have seen in section 3.4 above that en/ne binds the quantitative phrase and is not the clitic counterpart of a strong pronoun de elles / di loro which only realizes the partitive PP.

\subsubsection{Quantitative clitics as DPs}

Cardinaletti and Giusti $(1992 ; 2006)$ argue that ne is a quantitative DP. They offer three different kinds of evidence.

First, quantitative en in French and ne in Italian can co-occur with the PP complement of Q (see (34), (109b), and (129) above). This would be unexpected if these clitics were the counterparts of a partitive PP:
a. J'en ai lu beaucoup [en] de ceux que tu m'a renseigné.
I EN have read many of those that you to.me have advised
b. Ne ho letti molti [ne] di quelli che mi hai consigliato.
I NE have read many of those that [you] to.me have recommended

Second, quantitative ne in Italian behaves like DPs and unlike PPs in left-dislocation structures. It obligatorily resumes a left-dislocated phrase (165a), as happens with DPs (165b) but not with PPs, which are only optionally resumed by a clitic, (165c), (165d) (Cinque 1990):
a. Di ragazzi francesi, ${ }^{*}($ ne) ho conosciuti molti. of boys French,
[I] NE have met many
b. I ragazzi francesi, *(li) ho conosciuti. the boys French, [I] them have met
c. Di questo libro, (ne) hanno parlato molto bene. of this book, [they] NE have spoken very well
d. Con Maria, (ci) ho parlato ieri. with Maria, [I] CI have spoken yesterday


Third, quantitative ne triggers agreement on the past participle, like object clitics and unlike prepositional clitics, including non-quantitative ne (in this respect, Italian quantitative ne in (166) differs from French en, see section 4.4.1 above):
a. $\mathrm{Ne}$ ho conosciut $^{*} \mathrm{o} / \mathrm{i} / \mathrm{e}$ molti/e.
[I] NE have metM.SG/M/F.PL manyM/F.PL
b. $\mathrm{Li}$ ho conosciut ${ }^{*} \mathrm{o} / \mathrm{i}$.
[I] themM.PL have metM.SG/PL
c. $\mathrm{Ne}$ hanno parlato $/{ }^{*} \mathrm{a} /{ }^{*} \mathrm{i} /{ }^{*} \mathrm{e}$
[they] NE have spokenM/F.SG/M/F.PL very well
d. $\mathrm{Ci}$ ho parlato $/{ }^{*} \mathrm{a} /{ }^{*} \mathrm{i} /{ }^{*} \mathrm{e}$
ieri.
[I] with him/her/them have spokenM/F.SG/M/F.PL yesterday

If accusative object clitics are DPs, the parallel behavior of (165a) and (165b), on the one hand, and (166a) and (166b), on the other, can be captured by suggesting that ne is the clitic realization of the quantitative DP. In this perspective, ne is a syncretic form which stands for any number and gender, like the dative clitic gli in colloquial Italian, which stands for any gender and number (Gli ho parlato ieri '[I] to him/to her/to them have spoken yesterday'). This conclusion can be extended to French en. The fact that French en does not trigger past participle agreement (see (159c)) can be explained by observing that with accusative clitics, the agreeing past participle is the assigner of accusative Case, while with quantitative clitics, which receive partitive case from the selecting $Q$, past participle agreement is subject to parametric variation: Italian ne shares its phi-features, while French en does not (see Belletti and Rizzi 1996).

Lamiroy (1991a; 1991b), Ruwet (1990), and Vermandere (2002) take the opposite stand and suggest that quantitative $e n / n e$ in French and Italian are parallel to PPclitics. Vermandere (2002) accounts for the contrast in past participle agreement by assuming that the clitic en in French does not have [+N] features, unlike ne in Italian.

\subsubsection{Quantitative clitics as KIPs}

Zamparelli (2000) suggests that quantitative ne is a KIP (kind phrase; see section 2.3.4 above). This hypothesis is in part parallel to Cardinaletti and Giusti's $(1992 ; 2006)$ proposal that $n e$ is a DP. The common core of the two proposals is that ne stands for a projection that includes all complements and modifiers of the noun, the difference lying in the position of the quantifier (DP-internal vs. DP-external). Note that assuming the KIP status of quantitative ne makes it the only clitic pronoun that realizes an incomplete extended projection, while assuming a DP-status for ne takes all clitic pronouns as complete extended projections.

\subsubsection{Quantitative clitics as NPs}

There are two respects in which ne differs from accusative and dative object clitics: binding properties and co-occurrence with relative clauses. These properties led Belletti $(1993,115, \mathrm{fn} .34)$ and Cinque $(1991, \mathrm{fn} .7)$ to analyze ne as an NP, not a DP. This could be reformulated by assuming that ne resumes an incomplete projection. We now show that these asymmetries are only apparent, and that ne can be safely analyzed as DP on a par with the other (accusative and dative) object clitics. 
Quoting Cresti (1993), Belletti observes that quantitative ne in Italian obeys Principle $\mathrm{C}$ of the Binding Theory, disallowing binding from a c-commanding DP (see Cresti 2003, 87):

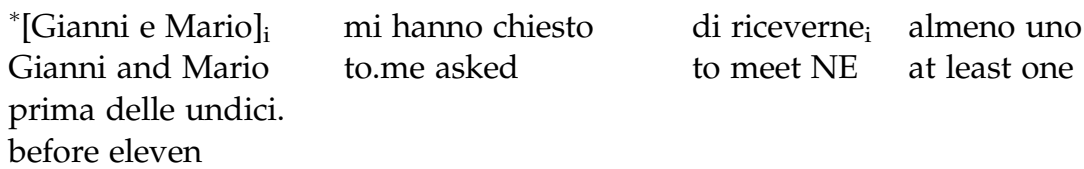

In this respect, Italian quantitative ne differs from DP clitics (accusative and dative), which obey Principle B of the Binding Theory, (168), and behaves like nonquantitative instances of ne, which are PPs and are excluded in c-command contexts, $(169 a)$ versus $(169 b):^{21}$
a. Gianni $\mathrm{i}_{\mathrm{i}}$ sostiene che Maria $\mathrm{lo}_{\mathrm{i}}$ conosce.
Gianni claims that Maria him knows
b. Gianni $i_{i}$ sostiene che Maria gli parlerà.
Gianni claims that Maria to.him will.talk

a. ${ }^{*}$ Gianni $_{\mathrm{i}}$ sostiene che Maria ne $\mathrm{i}_{\mathrm{i}}$ parla spesso.

Gianni claims that Maria NE talks often

b. Maria deve essere innamorata di Gianni $i_{i}$ perché ne parla sempre. Maria must be in love with Gianni because [she] NE talks always

However, unlike prepositional ne in (169b), Italian quantitative ne is also ungrammatical in a context where it is not c-commanded by its antecedent, as in (170):

(170) * Maria deve essere innamorata di [Gianni e Mario] ${ }_{i}$ perché vuole riceverne ${ }_{i}$ almeno uno prima delle undici.

Maria must be in love with Gianni and Mario because [she] wants to meet-NE at least one before eleven

The ungrammaticality of (170) cannot be due to a violation of the Binding Theory, but to the fact that quantitative ne cannot pronominalize a definite DP. The same explanation can account for (167). Definite DPs can only be pronominalized by the strong form di loro, as shown by (171), the grammatical counterparts of (167) and (170):

(171) a. [Gianni e Mario $]_{\mathrm{i}}$ mi hanno chiesto di ricevere almeno uno di loro $_{\mathrm{i}}$ prima delle undici.

Gianni and Mario asked me to meet at least one of them before eleven

b. Maria deve essere innamorata di Gianni e Mario ${ }_{i}$ perché vuole ricevere

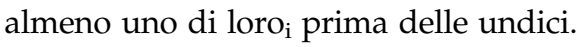

Maria must be in love with Gianni and Mario because [she] wants to meet at least one of them before eleven

In sum, binding-theoretic data cannot be used to argue against the DP analysis of $n e .^{22}$ Incidentally, note that these data support the proposal made above 
that ne is not the pronominal counterpart of the partitive PP, which can refer to a definite PP.

Cinque (1991, fn. 7) also proposes the NP-status for Italian ne, observing that ne can co-occur with a relative clause, while accusative and dative clitics cannot:
a. Di libri, ne ho letti of books, [I] NE have read two of which [I] not remember now the title
b. $\quad{ }^{*}$ I libri di Gianni, li ho letti the books of G., [I] them have read di cui non ricordo ora il titolo. of which [I] not remember now the title

Cinque explains the ungrammaticality of $(172 b)$ by proposing that accusative and dative clitics are DPs, which include the relative clause. The grammaticality of (172a) follows if quantitative $n e$ is an NP, which excludes the relative clause. Note, however, that Italian ne can also pronominalize a portion of structure that includes a relative clause:
Di libri
di cui non ricordo ora il titolo,
ne ho letti due.
of books of which [I] not remember now the title, [I] NE have read two

We would thus end up with two different analyses of quantitative ne: NP in (172a) and DP in (173). This would have the disadvantage of attributing different categories to one and the same vocabulary item, as noted in section 4.2 for the co-occurrence of ne with (apparent) arguments of the noun (see (149)).

\subsubsection{Quantitative clitics and English one}

The proposal that ne has NP status might lead one to analyze it on a par with other pro-NP elements such as English one, as suggested by an anonymous reviewer (also see Ellipsis in Noun Phrases). This parallel, however, does not hold. English one occurs with definite determiners (174a)-(174b) versus $(174 \mathrm{c})-(174 \mathrm{~d})$, and with prenominal adjectives (174e)-(174f). Italian quantitative ne displays the opposite behavior: it cannot occur with definite determiners (175a)-(175b) and prenominal adjectives (see the only prenominal forms bel and bei in (175e) and (175f)), while it is obligatory in object position with existential quantifiers (175d) and only possible with predicative postnominal adjectives (see the contrast bei/belli in (175f )) (see section 4.3 above):

(174) a. I read the one on the table.

b. I read these (ones).

c. I read many.

d. * I read many ones.

e. I read the nice one.

f. I read many nice ones.

(175) a. $\quad{ }^{*} \mathrm{Ne}$ ho letto il sul tavolo.

b. ${ }^{*}$ Ne ho letti questi.

c. ${ }^{*}$ Ho letto molti. 
d. Ne ho letti molti.

e. ${ }^{*}$ Ne ho letto il bel/bello.

f. Ne ho letti molti *bei/belli.

Panagiotidis (2003a; 2003b) makes a parallel among all semantically empty nouns, irrespective of their null or overt phonological status (as in the case of one in English). According to this author, an empty noun is a constitutive part of all pronouns, including strong and clitic personal pronouns, as well as pronominal forms of demonstratives and other determiners. In Panagiotidis' framework, the parallel to be drawn between ne and one is not their X-bar theoretic status, but the fact that being a pronoun, ne contains a semantically and phonologically empty $\mathrm{N}$, while one is the overt counterpart of the semantically empty $\mathrm{N}$, as also independently claimed by Schütze (2001).

\subsection{Quantitative er in Dutch}

In Dutch, quantitative er (176a) is homophonous to prepositional (176b), locative (176c), and expletive (176d) er (examples from Bennis 1986, sect. 3.2):
a. Ik heb er twee gekocht.
I have ER two bought
b. Ik heb met hem er over I have with him there about talked
c. Jan woont er nog maar kort. Jan lives there only briefly
d. Er kocht niemand een boek. there bought nobody a book

As for French en and Italian ne, the question arises as to whether quantitative er is to be analyzed as having the same category as the other instances of $e r .^{23}$

Van Riemsdijk $(1978,197)$ observes that quantitative er differs from the prepositional er found in PPs such as (177) (from Van Riemsdijk 1978, 87) in that it never occurs inside its own projection and does not have a $[+\mathrm{WH}]$ counterpart, (178):

a. vlak er na right ER after

b. Waar heb je op gerekend? where have you on counted? 'What did you count on?'

(178) a. *de verwoesting van er [drie er] the destruction of ER three 'the destruction of three of them'

b. "Waar heb je [drie arar]? where have you three? 'Of what do you have three?' 
Bennis $(1986,177)$ further points out that quantitative er differs from both prepositional and locative er in that it is not related to a paradigm of R-pronouns, (179). Quantitative er cannot be replaced by other R-pronouns such as hier and daar:

(179) a. *Ik heb hier gisteren [twee hier] gekocht.

I have here yesterday two bought

b. ${ }^{*} \mathrm{Ik}$ heb daar haar [veel daar] gegeven.

I have there to.her many given

Furthermore, quantitative er, unlike prepositional, locative, and expletive er, cannot occur in sentence-initial position (Bennis 1986, 177):

(180) a. *Er zijn [twee ex] verschenen.

ER are two appeared

b. *Er hebben enkele mensen haar [twee er] gegeven.

ER have some people to.her two given

These properties suggest that quantitative er is different from the other instances of er, which are presumably pro-PPs. ${ }^{24}$

Blom (1977) analyzes quantitative er as an $\mathrm{N}^{\prime}$. This proposal is also adopted by Bennis (1977) and Van Riemsdijk (1978). Quantitative er does not occur with the head noun (181a), nor with prenominal adjectives (181b). It, however, occurs with relative clauses and postnominal adjectives, (182):

(181) a. Ik heb (*er) drie boeken gekocht.

I have ER three books bought

b. Ik heb (*er) nog drie gele.

I have ER still three yellow

'I still have three yellow ones.'

(182) a. Ik heb er drie die vol zitten met luizen.

I have ER three that full sit with lice

'I have three that are full of lice.'

b. Ik kocht er een/'n groot.

I bought ER one big

On a par with the material left stranded by ne-cliticization in Italian, relative clauses and postnominal adjectives, as in (182), can be analyzed as predicative modifiers of the noun. As pointed out in Cinque $(1991,123)$, the postnominal adjective in (182b) has the same non-agreeing form that is found with predicative adjectives, (183a), not the agreeing form found with prenominal adjectives, as in (183b) (cf. * Ik kocht er een/'n groote and (181b)):

(183) a. De tafel is groot.

the table is big

b. Een/'n grote tafel

a big table 
Like Italian ne, Dutch er can co-occur with a partitive PP, as in (184a), provided the partitive PP has a null NP. Compare (184b) and (184c) with Italian (130): $:^{25}$

(184) a. Ik heb er twee gekocht van degene die je me aangeraden had. I have ER two bought of those that you to.me advised had

b. Ik heb ( $*$ er) [twee $e$ van deze boeken] gekocht. I have ER two of these books bought

c. [Twee $e$ van die boeken] heb ik (*er) gisteren gekocht. two of the books have I ER yesterday bought

The PP introduced by van is ambiguous between the "genuine" and the "adjunct" partitive PP interpretation (see section 3.2). It can be separated by the quantified expression and appear in the Mittelfeld or in sentence-initial position, as in (185) (Bennis 1986, 199, 251, fn. 8). In this case, er is obligatory, unlike (184b) and (184c), which supposedly contain a "genuine" partitive PP:

(185) a. Ik heb van die boeken *(er) gisteren [twee er] gekocht.

I have of the books ER yesterday two bought

b. Van deze boeken heb ik *(er) [twee er] gekocht. of these books have I ER two bought

When a partitive PP follows the quantifier, er gives rise to haplology: it can bind both the quantitative phrase and the R-position inside the PP, as in (186) (Bennis 1986, 199):

(186) Ik heb er gisteren [twee er] [van er] gekocht.

I have ER yesterday two of bought

Quantitative er gives rise to haplology also when it occurs with expletive, prepositional, and locative er, (187). It can even bind the empty category of two quantified expressions, one in subject position and one in object position, (188) (Bennis 1986, sect. 3.2.5):

a. expletive + quantitative

... dat er niemand [twee er] gekocht heeft.

that ER nobody two bought has

b. quantitative + prepositional

... dat Jan er [twee er] [over ex] gelezen heeft.

that Jan ER two about read has

c. quantitative + locative

Jan zou drie weken van zijn vakantie in Italië doorbrengen maar uiteindelijk heeft hij er maar [twee er] er doorgebracht.

Jan would three weeks of his holidays in Italy spend, but eventually has he ER only two spent

d. expletive + quantitative + prepositional

... dat er niemand [drie er] [over er] geschreven heeft.

that ER nobody three about written has 
e. expletive + quantitative + locative

... dat er nog maar [twee er] er woonden.

that ER yet only two lived

... dat er [twee er] [één er] gekocht hebben.

that ER two one bought have

'that two of them bought one of them'

\section{The empty quantitative phrase}

In this section, we discuss the contexts in which the quantitative phrase is null. The major question is whether it is a case of nominal ellipsis (see Ellipsis in Noun Phrases), as suggested for French by Ronat (1977), who unifies the nominal which appears with quantifiers with the null nominal that can be found in definite descriptions, such as le premier 'the first'.

Lobeck $(1995,42-45)$ unifies the empty nominals that appear with quantifiers, possessives, and demonstratives under the rubric of NP-ellipsis (some/John's/these [e] went home disappointed) and distinguishes it from gapping (see Gapping), which crucially does not involve a maximal projection. According to Lobeck, the ellipted $\mathrm{NP}$ is governed by strong features on the determiner, for this reason only determiners that have [+Plural] or [+Possessive] allow it. Insertion of an adjective blocks licensing by the determiner and requires the overt realization of the anaphoric $\mathrm{NP}$ as one (cf. many ("ones) vs. many blue *(ones); also cf. (174) above). Variation between English and French is derived by the assumption that in French, determiners are weak and cannot license a null category. Insertion of an adjective which is inflected for number features can do the job (cf. ${ }^{*} \mathrm{Ces}[e]$ sont plus intéressants 'These are more interesting' vs. Les grands [e] jouaient avec les petits $[e]$ 'The elder played with the younger').

Sleeman (1996) revises Lobeck's approach assuming that the feature licensing the null NP is [+partitive], which is associated to every determiner or prenominal adjective that can be found in the construction. This appears to be rather reasonable for those adjectives that induce a unique referential index and are compatible with a "collective" PP (see the discussion of (123)-(124) above), such as autre, premier, prochain, seul, and superlatives. It appears to be less tenable in the case of measure adjectives (grand and petit) and colour adjectives, which do not occur with collective PPs (see also Panagiotidis (2003b)).

For all approaches in which the quantitative phrase is larger than NP and includes prenominal adjectives, as Cardinaletti and Giusti (2006) and Zamparelli (2000), and for those that do not assume an empty quantitative element, as Schütze (2001), the parallel with NP-ellipsis is problematic.

It must, however, be considered that there is a crucial difference between the null quantitative phrase and NP-ellipsis, as noted by Panagiotidis (2000, 50), who explicitly excludes quantified nominals from his investigation on NP-ellipsis and oneanaphora. Observe the pattern that arises in Italian with the prenominal adjective 
prima in object (189) and subject (190) position. In (189a) and (190a), we see that it can occur with a definite and an indefinite determiner. The presence of prima is ungrammatical in (189b) and (190b) because only postnominal predicative adjectives can appear with quantitative null phrases (as observed by Rizzi (1979); see the discussion in section 2.1.2 above), as shown in (189c) and (190c). At the opposite side, the prenominal adjective prima is sufficient and necessary to have a null NP with a definite determiner in (189d)-(189e) and (190d)-(190e):

(189) a. Ho ascoltato una/la prima analisi dei dati veramente soddisfacente.

I have listened to a/the first analysis of the data really satisfying

b. ${ }^{*} \mathrm{Ne}$ ho ascoltata una prima [ne] (veramente soddisfacente).

I NE have listened to one first really satisfying

c. Ne ho ascoltata una [ne] veramente soddisfacente.

I NE have listened to one really satisfying

d. Ho ascoltato la * (prima) [e].

I have listened to the first.

e. Ho ascoltato la *(prima) [e] veramente soddisfacente.

I have listened to the first really satisfying

(190) a. Una/La prima analisi dei dati veramente soddisfacente ha dato questo risultato.

a/the first analysis of the data really satisfying has provided this result

b. *Una prima [e] (veramente soddisfacente) ha dato questo risultato.

a first has really satisfying provided this result

c. Una $[e]$ veramente soddisfacente darebbe questo risultato.

a really really satisfying would provide this result

d. La *(prima) [e] ha dato questo risultato.

the first has provided this result

e. $\quad$ La *(prima) [e] veramente soddisfacente ha dato questo risultato.

the first really satisfying has provided this result

In conclusion, as shown in (189c) and (190c), empty quantitative phrases have the same distribution as quantitative clitics: they occur with existential quantifiers and only with adjectives that can be predicative (see section 4.3 above).

The level of merger of the predicative adjective is subject to debate, as already discussed at various points in this chapter. The fact that predicative adjectives can co-occur with a null noun only in the presence of an overt quantifier suggests that they do not directly modify the empty quantitative phrase, but the whole quantified expression.

Let us now turn to the interpretation of the empty category. Two cases should be distinguished, exemplified here with Italian: (i) the quantitative phrase co-occurs with the partitive PP; (ii) the quantitative phrase occurs by itself. In the former case, the non-distinctness requirement discussed in section 3.4 plays a crucial role in the interpretation of the empty quantitative phrase. Its intension can be directly recovered from the intension of the partitive PP (191), while its Number is recovered by overt agreement with the quantifier (plural in (191a), singular in (191b)). Note that the same happens when the quantitative phrase is overt and the noun phrase inside the partitive PP is empty (192): ${ }^{26}$ 
(191) a. molti [e] dei libri/ di quei libri

many of-the books/ of those books

b. uno $[e]$ dei libri/ di quei libri

one of the books/ of those books

(192) a. molti libri di quelli $[e]$ che mi hai consigliato

many books of those that [you] to.me have recommended

b. un libro di quelli $[e]$ che mi hai consigliato

one book of those that [you] to.me have recommended

In the latter case - that is, when the partitive PP is not present - the same interpretations are found as in other elliptic structures: the empty quantitative phrase either gets an anaphoric interpretation, or a default [+human] interpretation (see Corblin 1995; Cardinaletti and Giusti 1992; 2006; Kester 1996a; 1996b).

When the quantified expression occupies the subject position, as in Italian here, it agrees with the verb. The overt phi-features on $\mathrm{T}$ license the empty quantitative phrase, which is interpreted on the basis of an antecedent (193a) or gets a default [+human] interpretation in generic statements (193b):
a. Molti/e/Tre
[e] sono troppo costosi/e.
many.M/F/three
$\begin{array}{lll}\text { b. } & \begin{array}{l}\text { Molti } \\ \text { many.m }\end{array}\end{array} \quad \begin{aligned} & \text { non sanno che ... } \\ & \text { don't know that ... }\end{aligned}$

In Italian, in postverbal subject position, an empty quantitative phrase is only allowed with quantifiers that display overt number and gender features, e.g. molte, uno, and una, but not cardinals such as tre: ${ }^{27}$
a. Ieri hanno telefonato tre / molte ragazze. yesterday have telephoned three / many girls
b. Ieri hanno telefonato *?tre / molte [e].
c. Ieri ha telefonato uno / una [e].
yesterday has telephoned one.M.SG / one.F.SG

The empty phrase in (194b) and (194c) gets the same arbitrary [+human] reference found with null objects (see Rizzi 1986; Cinque 1988, fn. 36). This is shown by the contrast in (196). Similarly, (196b) can only mean that some human beings make nests, and the sentence is marked as anomalous. ${ }^{28}$ In (196c) and (196c), we see that a null quantitative phrase in prenominal subject position is acceptable in Italian, provided that dogs have been introduced in the discourse, as expected, given (193a) above:
a. Hanno telefonato molti $[e]$. have telephoned many [people]
b. *Hanno abbaiato molti [e]. have barked many [dogs]
c. Molti $[e]$ hanno abbaiato. many [dogs] have barked 
(196) a. (Questo tipo di nido), lo fanno molti uccelli migratori. (this kind of nest), it make many migrating birds

b. \#(Questo tipo di nido), lo fanno molti [e].

c. Molti $[e]$ fanno questo tipo di nido. many [birds] make this type of nest

As expected, in Italian, the same restriction holds for quantifiers in object position, where the intension cannot be recovered and the interpretation is limited to [+human] arbitrary reference:
a. Ieri
ho incontrato
molti $[e]$
per la strada.
yesterday
[I] have met
many [people]
on my way

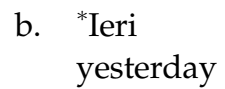
ho letto
molti [e]
in biblioteca.
[I] have read
many [things]
in the library

Things seem to be different in Italian with universal quantifiers. In postverbal subject position, [-human] interpretation of the null quantitative phrase is possible. Contrast the anomalous (196b) with (198b):
a. (Questo tipo di nido), lo fanno tutti gli uccelli migratori. (this kind of nest), it make all the migrating birds
b. (Questo tipo di nido), [pro] lo fanno tutti [pre]. (this kind of nest), it make.3PL all
c. Tutti $[e]$ fanno questo tipo di nido. all make.3PL this kind of nest

The postverbal subject position of a universal quantifier is, however, different from that of an existential quantifier. In (198b), we are dealing with floating tutti related to a null subject. Note that floating is not possible in Italian with existential quantifiers (see Giusti 1990, and note 2).

In syntactic positions out of which floating cannot take place, such as the object position in Italian, universal quantifiers can only co-occur with an arbitrary thirdperson [+human] quantitative phrase (199a), on a par with existential quantifiers (197). Sentence (199b) is anomalous due to the fact that a [+human] interpretation is incompatible in our encyclopedic knowledge with the thematic roles assigned by vendere 'sell':
a. Ho visto
[I] have seen
all
on the street
tutti [e] per la strada.
b. "Ho venduto tutti $[e]$.
[I] have sold all

In conclusion, empty quantitative phrases and empty pronouns have a more limited distribution than NP-ellipsis, although they share the same interpretive strategies. 


\section{Conclusions}

The aim of this chapter was to provide an insight into the structure of quantity expressions and quantitative clitics. These issues have been presented as two sides of the same coin. Since quantitative clitics arise with a restricted number of quantifiers, we have first addressed the issue of the structure of quantified expressions, then we have turned to the possible analyses given to quantitative clitics. In so doing, we have also dealt with partitive constructions, which often, but not always, appear in the same contexts as quantitative clitics, and with nominal ellipsis which partially appears to be in complementary distribution with quantitative clitics in languages that have this type of clitics, and to be parallel to nominal ellipsis in languages that do not have such clitics.

In the course of the chapter, we have tried to present the competing analyses put forth in the literature from the early days of generative grammar to the present (more than four decades of linguistic search), privileging the empirical contribution and the general insight of each product of research, and trying to overlook technicalities, which vary most evidently over time and which the interested reader can turn to.

What seems to be established is that quantitative clitics are smaller projections than the quantified expressions they are associated with and that they obey a number of restrictions that make them similar to, but at the same time different from, other clitic pronouns.

All linguistic analyses display a tension towards economy, simplification, and generalization in their efforts to explain differences and similarities arising from empirical data. The discussion we have presented has regarded possible generalizations on:

- the categorial status of quantity items;

- the categorial status of quantitative and direct case clitics;

- the categorial status of null portions of nominal expressions known as nominal ellipsis and the empty category linked to a quantitative clitic;

- the structure of quantified expressions with and without a partitive PP;

- the level of attachment of partitive PPs of different types.

As is often the case in linguistic research, we have found the usual short-blanket effect: if we generalize the data or simplify the explanation on one side, we must complicate the analysis on the other side. The issue is always whether the complication is independently needed and empirically motivated or just ad hoc. In many cases, the border between the two is not so clear-cut as one may wish. Our hope is that we have provided the reader with solid tools of analysis to continue the research on their own.

\section{Acknowledgments}

This chapter was co-written from beginning to end. However, to meet the legal requirements of the Italian academy, Giuliana Giusti is responsible for sections 1-3.1 and Anna Cardinaletti is responsible for sections 3.2-5. We are indebted to 
Roberto Zamparelli for precise comments and constructive criticism on the first version of Cardinaletti and Giusti (2006), and to Lucia Tovena for long discussions with Giuliana Giusti on the semantics of partitivity in October 2012. We also thank an anonymous reviewer for constructive criticism. All errors are undoubtedly ours.

SEE ALSO: Bare Nouns; Ellipsis in Noun Phrases; Gapping; Left Dislocation; Measure Phrases and Semi-Lexical Nouns; Partitive Constructions; (Past) Participle Agreement; Quantifier Scope Ambiguities; Quantifier-Float; Split Topicalization; Syntactic Haplology

\section{Notes}

1. Jackendoff's proposal is alternative to previous ones deriving quantified NEs from quite different deep structures: Hall (1962) considered some of the to be a structured Det, thereby losing the constituency of the PP of the men; Dean (1966) derived some of the men from some men of the men with deletion of the first instance of men (we turn to a similar proposal in section 3 below); Lakoff (1965) and Carden (1967) considered the construction to be derived from a relative clause whose predicate is the quantifier.

2. Giusti (1990) claims that floating is the result of independently motivated movement of the DP. Floating with universal quantifiers is related to movement in search of case. Floating with existential quantifiers, which assign partitive case, cannot be related to the subject position. (59) is possible in V2 languages because it involves a non-Case position.

3. More recently Martí i Girbau (2010) also argues for the lexical nature of quantifiers which correlates with different selectional properties of subclasses of Qs. Her analysis is, however, quite different, as she claims that Qs can either select a PP or an NP, but not both at the same time (see section 2.3.4 below).

4. This generalization is only apparently contradicted by the English gloss. See section 3.5 for discussion.

5. Quirk et al. $(1985,263,759)$ note that in this case the predicate is singular; compare Many a member has protested against the proposal. Plural interpretation with singular morphology is not exceptional if we consider the singular number on every and each which is associated to universal interpretation.

6. Ganz can also be an adverb meaning 'entirely', 'completely'.

7. In considering the Romanian examples, one must keep in mind that the enclitic article in Romanian appears on the leftmost lexical head in the DP, namely N or A (see Grosu 1988 and Giusti 1993, among others).

8. The split DP structure has been argued for in different proposals to account for different empirical domains (see Beghelli 1995; Giusti 1996; Sleeman 1996; Beghelli and Stowell 1997; Aboh 1999; Schütze 2001; Ihsane 2008; Cinque 2010, among many).

9. See Kayne (1994) and Den Dikken (1998) for the seminal proposal and Corver and Zwarts (2006) for an application to quantified nominals.

10. Cinque (1991) shows that in Italian, a PP such as in medicina in (106) is a complement of $\mathrm{N}$, since it cannot be used predicatively:

(i) ${ }^{*}$ Questi due studenti sono in medicina. these two students are in medicine

11. Note that $(107 \mathrm{c})$ can be reinterpreted as the "kind" PP discussed in section 3.3, with the interpretation of 'the kind of students who sit in your course'. 
12. The intension is realized in the lexical layer and includes gender. Compare Italian (i) with (121):
(i) a. ${ }^{*}$ Conoscevo molte ragazze dei ragazzi che erano alla festa.
[I] had met many girls.F.PL of-the boys.M.PL that were at the party
b. ${ }^{*}$ Conoscevo una ragazza dei ragazzi che erano alla festa.
[I] had met a girl.F.SG of-the boys.M.PL that were at the party

13. Entrambi belongs to a high register. Instead of entrambi noi, Italian can have noi due, namely a cardinal with universal interpretation in the order "quantitative phrase $>Q$ ", as in (i), where the pronoun has moved to SpecQP (see (57) above):

(i) [QP Noi [ $\mathrm{Q}^{\prime}$ due/venti/cinquecento [DP nei]]] abbiamo un unico obiettivo. we two/twenty/five hundred have.1PL a common goal

This order cannot be derived by the usual existential interpretation of cardinals, represented in (ii), in which the pronoun occurs inside the partitive PP:

(ii) [QP Due/Venti/Cinquecento [DP e] ${ }^{*}$ (di) noi] hanno/*abbiamo un unico obiettivo. two/twenty/five hundred of us have.3PL/1PL a common goal

The Person feature of the verb shows that in (i) the quantitative phrase is the first-person plural pronoun, while in (ii) the quantitative phrase is a third-person plural null category. Therefore noi due and due di noi have completely different structures.

14. The analysis in (129d) differs from Belletti's $(1979,1559)$, according to which di cui is left-dislocated and resumed by ne.

15. Assignment of partitive case to indefinite nominal expressions is cast in a consolidated line of research which correlates (in)definiteness / (non)specificity with case morphology (see Pesetsky 1982; 2013; Belletti 1988; Enç 1991; Kornfilt 1996; Vainikka and Maling 1996; Kiparsky 1998; Abraham and Leiss 2012; Boivin 2005, among many).

16. It is often assumed that clitic movement can be decomposed into two steps: XP movement followed by X-movement (Sportiche 1989; Belletti 1999; Cardinaletti and Starke 1999, sect. 6.3). The clitic pronoun is first moved as an XP to the specifier of QP (see (57) above) and further moved to the specifier of the past participle, triggering agreement with it (see (166a) below; see Kayne 1989; Belletti and Rizzi 1996), before cliticizing to T.

17. Sentence (157c) can be marginally acceptable for those Italian speakers who can reinterpret the infinitival introduced by $d i$ as a purpose clause usually introduced by per, as shown in (ia). This possibility also arises with the overt noun in (157a), as shown in (ib):

(i) a. Di modi, ce ne sono due per/?di risolvere il problema.

of ways there NE are two to solve the problem

b. Ci sono due modi, per/?di risolvere il problema.

there are two ways to solve the problem

The occurrence of the prepositional complementizer per guarantees that the infinitival clause is not a complement of the noun modo, since in Italian, this preposition introduces a purpose (infinitival) clause.

18. En triggers past participle agreement in some French varieties (Grevisse 1986, sect. 910).

19. In a framework that allows deletion operations, Kayne assumes that the preposition de is deleted in order to get the grammatical deux sœurs. 
20. Milner $(1978,138)$ notes for French that left- and right-dislocation behave differently in this respect. Agreement in number is required in right-dislocation. His data can be reproduced in Italian:
(i) a. De cheval/chevaux, j'en ai un. of horse/horses, [I] NE have one
a' Di cavallo/cavalli, ne ho uno. of horse/horses, [I] NE have one
b. De ?cheval/chevaux, j'en ai deux. of horse/horses, [I] NE have two
b' Di *avallo/cavalli, ne ho due. of horse/horses, [I] NE have two
(ii) a. J'en ai un, de cheval/*' chevaux. [I] NE have one, of horse/horses
a' Ne ho uno, di cavallo/*cavalli. [I] NE have one, of horse/horses
b. J'en ai deux, de *heval/chevaux. [I] NE have two, of horse/horses
b' Ne ho due, di *cavallo/cavalli. [I] NE have two, of horse/horses

21. For similar binding facts of French en, see Ruwet (1990), Lamiroy (1991a; 1991b), and Vermandere (2002).

22. As observed by Lamiroy (1991a, 411, fn.6) and (1991b, 43), French en does not show any anti-reflexive effect:
(i) Cet/Un homme en $_{\mathrm{i}}$ vaut un autre. this/a man EN is worth another
'This/A man is worth any other man.'

She concludes that en does not enter coreference relationships and is exempted from Binding Theory.

23. Bennis $(1986,251$, fn. 10) notes that "all proposals concerning quantitative er explicitly or implicitly consider quantitative er to be homonymous with the weak form of the R-paradigm which we find with prepositional and locative er." However, "historically quantitative er developed from a different source, a genitive form of the 3rd Person singular, iro."

24. The fact that quantitative er cannot occur in specifier positions (PP-internally (178a) and in sentence-initial position (180)) might suggest that it differs from the other instances of er not only in categorial status but in another respect as well. Since clitic pronouns cannot end up in specifier positions (Cardinaletti and Starke 1999), quantitative $e r$ can be taken to be a clitic pronoun, while the other instances of er can be weak pronouns.

25. Unlike Italian, Dutch allows for an empty category to co-occur with a prenominal agreeing adjective, in which case er is ungrammatical. See (181b) and (i), which is a case of NP-ellipsis (see section 5 and Lobeck 1991; 1993, 1995; Kester 1996a; 1996b; Sleeman 1996, Llombart-Huesca 2002):
(i) Ik heb (*er) [een rode $e$ ] gekocht.
I have ER a red bought

In this respect, Dutch is similar to other Germanic languages. Compare (i) with the parallel German example in (ii).
(ii) Ich habe ein rotes [e] gekauft.
I have a red [one] bought

26. The phrase embedded in the partitive PP can also contain a pronominal demonstrative, as in Italian (i). In this case, the content of the quantitative phrase is recovered from the context, as in the case discussed below: 


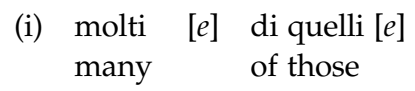

27. The Italian sentence in (i) is also ungrammatical with ne. Ne cannot be extracted from a postverbal subject (see section 2.2 above):

$\begin{array}{lllll}\text { (i) }{ }^{*} \text { Ieri } & \text { ne hanno telefonato tre/molte/uno/una [ne]. } \\ \text { yesterday } & \mathrm{NE} & \text { have telephoned } & \text { three/many.F.PL/one.M/one.F }\end{array}$

28. But (196b) can obviously be felicitous in a context in which human beings make nests, e.g. in order to attract migrating birds into their gardens.

\section{References}

Abney, Steven P. 1987. “The English Noun Phrase in Its Sentential Aspect." PhD diss., MIT. Aboh, Enoch. 1999. From the Syntax of Gungbe to the Grammar of Gbe. Sierre: Editions à la carte.

Abraham, Werner, and Elisabeth Leiss. 2012. "The Case Differential: Syntagmatic versus Paradigmatic Case - Its Status in Synchrony and Diachrony." Transactions of the Philological Society, 110 (3): 316-341.

Barker, Christopher. 1998. "Partitives, Double Genitives and Anti-Uniqueness." Natural Language and Linguistic Theory, 16: 679-717.

Barwise, Jon, and Robin Cooper. 1981. "Generalized Quantifiers and Natural Language." Linguistics and Philosophy, 4 (2): 159-219.

Battye, Adrian. 1987. "Quantificatori Nominali in Francese." In Ipotesi e applicazioni di teoria linguistica: Dal XIII incontro di grammatica generativa, edited by Patrizia Cordin, 9-27. Trento: Università di Trento.

Beghelli, Filippo. 1995. “The Phrase Structure of Quantifier Scope.” PhD diss., UCLA.

Beghelli, Filippo, and Timothy Stowell. 1997. "Distributivity and Negation: The Syntax of each and every." In Ways of Scope Taking, edited by Anna Szabolcsi, 71-108. Dordrecht: Kluwer.

Belletti, Adriana. 1979. "Sintagmi nominali quantificati e strutture dislocate a sinistra." Annali della Scuola Normale Superiore, Classe di Lettere e Filosofia, serie III, IX, 4: 1525-1568.

Belletti, Adriana. 1988. "The Case of Unaccusatives." Linguistic Inquiry, 19: 1-34.

Belletti, Adriana. 1993. "Case Checking and Clitic Placement: Three Issues on (Italian/ Romance) Clitics." GenGenP, 1 (2): 101-118.

Belletti, Adriana. 1999. "Italian/Romance Clitics: Structure and Derivation." In Clitics in the Languages of Europe, edited by Henk van Riemsdijk, 543-579. Berlin: De Gruyter.

Belletti, Adriana, and Luigi Rizzi. 1981. "The Syntax of ne: Some Theoretical Implications." Linguistic Review, 1: 117-154.

Belletti, Adriana, and Luigi Rizzi. 1996. "Su alcuni casi di accordo del participio passato in francese e in italiano." In Italiano e dialetti nel tempo: Saggi di grammatica per Giulio C. Lepschy, edited by Paola Benincà, Guglielmo Cinque, Tullio de Mauro, and Nigel Vincent, 7-22. Rome: Bulzoni.

Benincà, Paola, and John Haiman. 1992. The Rhaeto-Romance Languages. London: Routledge Bennis, Hans. 1977. "Het kwantitatieve er in komparatiefkonstrukties." Spektator, 6 (7/8): 384-386.

Bennis, Hans. 1986. Gaps and Dummies. Dordrecht: Foris. 
Blom, Alied. 1977. "Het kwantitatieve er." Spektator, 6 (7/8): 387-394.

Boivin, Marie-Claude. 2005. "Case Theory, DP Movement, and Interpretation: A New Approach to the Distribution of French Subnominal Clitic en." Natural Language and Linguistic Theory, 23: 543-593.

Bresnan, Joan. 1973. "Syntax of the Comparative Clause Construction in English." Linguistic Inquiry, 4: 275-343.

Burzio, Luigi. 1986. Italian Syntax: A Government-Binding Approach. Dordrecht: Reidel.

Carden, Guy. 1967. “English Quantifiers.” MA diss., Harvard University.

Cardinaletti, Anna, and Giuliana Giusti. 1992. "Partitive ne and the QP-Hypothesis." In Proceedings of the XVII Meeting of Generative Grammar, edited by Elisabetta Fava, 121-141.

Cardinaletti, Anna, and Giuliana Giusti. 2006. "The Syntax of Quantified Phrases and Quantitative Clitics." In The Blackwell Companion to Syntax, edited by Martin Everaert and Henk van Riemsdijk, 5: 23-93. Oxford: Blackwell.

Cardinaletti, Anna, and Michal Starke. 1999. "The Typology of Structural Deficiency: A Case Study in the Three Classes of Pronouns." In Clitics in the Languages of Europe, edited by Henk van Riemsdijk, 145-233. Berlin: De Gruyter.

Casadio, Claudia. 1995. "Pronomi partitivi: il contrasto weak/strong." Lingua e Stile, 30 (3): 551-563.

Chierchia, Gennaro. 1998. "Referents to Kinds across Languages." Natural Language Semantics, 6: 339-405.

Chomsky, Noam. 1970. "Remarks on Nominalization." In Readings in English Transformational Grammar, edited by Roderick A. Jacobs and Peter S. Rosenbaum, 184-221. Boston, MA: Ginn.

Cinque, Guglielmo. 1988. “On si-Constructions and the Theory of arb." Linguistic Inquiry, 19: 521-581.

Cinque, Guglielmo. 1990. Types of A' Dependencies. Cambridge, MA: MIT Press.

Cinque, Guglielmo. 1991. "Lo statuto categoriale del ne partitivo." In Saggi di linguistica e di letteratura in memoria di Paolo Zolli, edited by Giampaolo Borghello, Manlio Cortelazzo, and Giorgio Padoan, 117-126. Padova: Editrice Antenore.

Cinque, Guglielmo. 1994. "On the Evidence for Partial N-Movement in the Romance DP." In Paths towards Universal Grammar, edited by Guglielmo Cinque, Jan Koster, Jean-Yves Pollock, et al., 85-110. Washington, DC: Georgetown University Press.

Cinque, Guglielmo. 2010. The Syntax of Adjectives: A Comparative Study. Cambridge, MA: MIT Press.

Corblin, Francis. 1990. "Les group nominaux sans nom du Français." In L'anaphore et ses domaines, edited by Georges Kleiber and Jean-Emmanuel Tyvaert, 63-80. Paris: Klincksieck.

Corblin, Francis. 1995. Les formes de reprise dans le discours. Rennes: Presses Universitaires de Rennes.

Corver, Norbert, and Joost Zwarts. 2006. "Prepositional Numerals." Lingua, 116 (6): 811-835.

Cresti, Diana. 1993. "Partitive and Existentials." MS, Université de Genève.

Cresti, Diana. 2003. "Aspects of the Syntax and Semantics of ne." In The Syntax of Italian Dialects, edited by Christina Tortora, 67-101. New York, NY: Oxford University Press.

Dean, Janet. 1966. "Determiners and Relative Clauses." MS, MIT.

Dikken, Marcel den. 1998. "Predicate Inversion in DP." In Possessors, Predicates and Movement in the Determiner Phrase, edited by Artemis Alexiadou and Christopher Wilder, 177-214. Amsterdam: John Benjamins.

Doetjes, Jenny. 1997. "Quantifiers and Selection: On the Distribution of Quantifying Expressions in French, Dutch and English." PhD diss., Leiden University.

Enç, Mürvet. 1991. "The Semantics of Specificity." Linguistic Inquiry, 22 (1): 1-25.

Fiengo, Robert. 1974. "Semantic Conditions on Surface Structures." PhD diss., MIT. 
Giorgi, Alessandra, and Giuseppe Longobardi. 1991. The Syntax of Noun Phrases: Configuration, Parameters, and Empty Categories. Cambridge: Cambridge University Press.

Giusti, Giuliana. 1990. "Floating Quantifiers, Scrambling and Configurationality." Linguistic Inquiry, 21: 633-641.

Giusti, Giuliana. 1991a. "The Categorial Status of Quantified Nominals." Linguistische Berichte, 136: 438-452.

Giusti, Giuliana. 1991b. "La sintassi dei nominali quantificati in Romeno." Rivista di Grammatica Generativa, 16: 29-57.

Giusti, Giuliana. 1993. La sintassi dei determinanti. Padua: Unipress.

Giusti, Giuliana. 1994. "L'ordine NQ in lingue QN." In Studi di Grammatica Tedesca e Comparativa, edited by Roberto Dolci and Giuliana Giusti, 49-66. Venice: Ca' Foscari, Centro Linguistico Interfacoltà.

Giusti, Giuliana. 1995. "Heads and Modifiers among Determiners." In Advances in Roumanian Linguistics, edited by Guglielmo Cinque and Giuliana Giusti, 103-125. Amsterdam: John Benjamins.

Giusti, Giuliana. 1996. "Is there a TopP and a FocP in the Noun Phrase Structure?" University of Venice Working Papers in Linguistics, 6: 106-128.

Giusti, Giuliana, and Nedžad Leko. 1996. "Universal and Indefinite Quantity Expressions in Bosnian." In Determinatezza e indeterminatezza nelle lingue Slave, edited by Rosanna Benacchio, Francesca Fici, and Lucyna Gebert, 147-162. Padua: Unipress.

Giusti, Giuliana, and Nedžad Leko. 2001. "The Categorial Status of Quantity Expressions." In Current Issues in Formal Slavic Linguistics, edited by Gerhild Zybatow, Uwe Junghanns, Grit Mehlhorn, and Luka Szucsich, 96-105. Frankfurt am Main: Peter Lang.

Grevisse, Maurice. 1986. Le bon usage, 12th ed. Paris: Duculot.

Grosu, Alexander. 1988. "On the Distribution of Genitive Phrases in Romanian." Linguistics, 26: 931-120.

Haïk, Isabelle. 1982. “On Clitic en in French."Journal of Linguistic Research, 1: 134-175.

Hall, Barbara. 1962. "All about Predeterminers." MS, MIT.

Hoeksema, Jacob, ed. 1996. Partitives: Studies in the Syntax and Semantics of Partitive and Related Constructions. Berlin: De Gruyter.

Hoop, Helen de. 1997. "A Semantic Reanalysis of the Partitive Constraint." Lingua, 103: 151-174.

Ihsane, Tabea. 2008. The Layered DP: Form and Meaning of French Indefinites. Amsterdam: John Benjamins.

Jackendoff, Ray S. 1968. "Quantifiers in English." Foundations of Language, 4: 422-442.

Jackendoff, Ray S. 1972. Semantic Interpretation and Generative Grammar. Cambridge, MA: MIT Press.

Jackendoff, Ray S. 1977. X'-Syntax: A Study of Phrase Struture. Cambridge, MA: MIT Press.

Kayne, Richard S. 1975. French Syntax: The Transformational Cycle. Cambridge, MA: MIT Press.

Kayne, Richard S. 1979. "ECP extensions." MS, Université de Paris VIII (revised version without the appendix published in Linguistic Inquiry, 12: 93-133).

Kayne, Richard S. 1989. "Facets of Romance Past Participle Agreement." In Dialect Variation and the Theory of Grammar, edited by Paola Benincà, 85-103. Dordrecht: Foris.

Kayne, Richard S. 1994. The Antisymmetry in Syntax. Cambridge, MA: MIT Press.

Kester, Ellen-Petra. 1996a. "Adjectival Inflection and the Licensing of Empty Categories in DP." Journal of Linguistics, 32: 57-78.

Kester, Ellen-Petra. 1996b. "The Nature of Adjectival Inflection." PhD diss., Utrecht University. Kiparsky, Paul. 1998. "Partitive Case and Aspect." In The Projection of Arguments: Lexical and Compositional Factors, edited by Miriam Butt and Wilhelm Geuder, 265-306. Stanford, CA: CSLI Publications. 
Koopman, Hilda, and Dominique Sportiche. 1985. "Theta Theory and Extraction." GLOW Newsletter, 14: 57-58.

Koopman, Hilda, and Dominique Sportiche. 1991. "The Position of Subjects." Lingua, 85: 211-258.

Kornfilt, Jaklin. 1996. "Naked Partitive Phrases in Turkish." In Partitives, edited by Jacob Hoeksema, 107-142. Berlin: De Gruyter.

Kupferman, Lucien. 1999. "Reflexions sur la partition: Les groupes nominaux partitifs et la relativisation." Langue française, 122: 30-51.

Kupferman, Lucien. 2004. Le mot 'de'. Brussels: Duculot.

Ladusaw, William A. 1982. "Semantic Constraints on the English Partitive Construction." In Proceedings of WCCFL 1, 231-242.

Lakoff, George. 1965. “On the Nature of Syntactic Irregularity,” Appendix F, Report NSF-16, Harvard Computation Laboratory.

Lamiroy, Béatrice. 1991a. "Binding Properties of French en." In Interdisciplinary Approaches to Language: Essays in Honor of S.Y. Kuroda, edited by Carol Georgopoulos and Roberta Ishihara, 397-413. Dordrecht: Kluwer.

Lamiroy, Béatrice. 1991b. "Coréférence et référence disjointe: les deux pronoms en." Travaux de Linguistique, 22: 41-65.

Leko, Nedžad. 2009. The Syntax of Numerals in Bosnian. Amsterdam: Lincom.

Llombart-Huesca, Amàlia. 2002. "Anaphoric one and NP-ellipsis." Studia Linguistica, 56 (1): $59-89$.

Lobeck, Anne. 1991. "The Phrase Structure of Ellipsis." In Perspectives on Phrase Structure: Heads and Licensing, edited by Susan Rothstein, 81-103. San Diego, CA: Academic Press.

Lobeck, Anne. 1993. "Strong Agreement and Identification: Evidence from Ellipsis in English." Linguistics, 31: 777-811.

Lobeck, Anne. 1995. Ellipsis: Functional Heads, Licensing, and Identification. New York, NY: Oxford University Press.

Longobardi, Giuseppe. 1994. "Reference and Proper Names: A Theory of N-Movement in Syntax and Logical Form." Linguistic Inquiry, 25: 609-665.

Lopez, Luis. 2000. "Ellipsis and Discourse Linking." Lingua, 110 (2): 183-213.

Martí i Girbau, Núria. 1995. "De in Catalan Elliptical Constructions: A Partitive Case Marker." Catalan Working Papers in Linguistics, 4 (2): 243-265.

Martí i Girbau, Núria. 1999. "Towards a Unitary Analysis of Partitive and Quantitative Constructions." Oxford University Working Papers in Linguistics, Philology \& Phonetics, 4: 84-101.

Martí i Girbau, Núria. 2010. "The Syntax of Partitives." PhD diss., Universitat Autònoma de Barcelona.

Matthewson, Lisa. 2001. "Quantification and the Nature of Cross-Linguistic Variation." Natural Language Semantics, 9: 145-189.

Milner, Jean Claude. 1978. De la syntaxe à l'interpretation. Paris: Editions de Seuil.

Milsark, Gary. 1977. "Towards an Explanation of Certain Peculiarities in the Existential Construction in English." Linguistic Analysis, 3: 1-30.

Panagiotidis, Phoevos. 2000. "Pronominals and Empty Noun Heads: 'Pronominality' and Licensing in Syntax." PhD diss., University of Essex.

Panagiotidis, Phoevos. 2003a. "Empty Nouns." Natural Language and Linguistic Theory, 21: 381-432.

Panagiotidis, Phoevos. 2003b. “One, Empty Nouns, and Ө-Assignment." Linguistic Inquiry, 34: 281-292.

Pesetsky, David. 1982. "Paths and Categories." PhD diss., MIT.

Pesetsky, David. 2013. Russian Case Morphology and the Syntactic Categories. Cambridge, MA: MIT Press.

Pollock, Jean-Yves. 1986. "Sur la syntaxe de en et le paramètre du sujet nul." In La grammaire modulaire, edited by Mitsou Ronat and Daniel Couquaux, 211-246. Paris: Editions de Minuit. 
Quirk, Randolph, Sidney Greenbaum, Geoffrey Leech, and Jan Svartvik. 1985. A Comprehensive Grammar of the English Language. London: Longman.

Riemsdijk, Henk van. 1978. A Case Study in Syntactic Markedness. Dordrecht: Foris.

Riemsdijk, Henk van. 1989. "Movement and Regeneration." In Dialect Variation and the Theory of Grammar, edited by Paola Benincà, 105-139. Dordrecht: Foris.

Ritter, Elisabeth. 1988. "A Head-Movement Approach to Construct State Noun Phrases." Linguistics, 26: 909-929.

Ritter, Elisabeth. 1991. "Two Functional Categories in Noun Phrases: Evidence from Hebrew." In Perspectives on Phrase Structure: Heads and Licensing, edited by Susan D. Rothstein, 37-62. San Diego, CA: Academic Press.

Rizzi, Luigi. 1979. "Teoria della traccia e processi fonosintattici." Rivista di Grammatica Generativa, 4 (1-2): 165-181.

Rizzi, Luigi. 1986. "Null Objects in Italian and the Theory of pro." Linguistic Inquiry, 17: 501-558.

Ronat, Mitsou. 1977. “Une contrainte sur l'effacement du nom.” In Langue, edited by Mitsou Ronat, 153-169. Paris: Herman.

Ruwet, Nicolas. 1972. Théorie syntaxique et syntaxe du français. Paris: Editions du Seuil.

Ruwet, Nicolas. 1990. “En et $y$ : deux clitiques pronominaux antilogophoriques." Langages, 97: 51-81.

Schütze, Carson. 2001. "Semantically Empty Lexical Heads as Last Resorts.” In Semi-Lexical Categories: The Function of Content Words and the Content of Function Words, edited by Norbert Corver and Henk van Riemsdijk, 127-187. Berlin: De Gruyter.

Selkirk, Elisabeth. 1977. "Some Remarks on Noun Phrase Structure." In Formal Syntax, edited by Peter W. Culicover, Thomas Wasow, and Adrian Akmajian, 285-325. London: Academic Press.

Shlonsky, Ur. 1991. "Quantifiers as Functional Heads: A Study of Quantifier Float in Hebrew." Lingua, 84: 159-180.

Sleeman, Petra. 1996. Licensing Empty Nouns in French. The Hague: HIL.

Sportiche, Dominique. 1988. "A Theory of Floating Quantifiers and Its Corollaries for Constituent Structure." Linguistic Inquiry, 19: 425-449.

Sportiche, Dominique. 1989. "Movement, Agreement and Case." MS, UCLA.

Szabolcsi, Anna. 1987. "Functional Categories in the Noun Phrase." In Approaches to Hungarian, edited by Istvan Kenesei, 2: 167-189. Szeged: Jate.

Toman, Jindřich. 1986. "Cliticization from NPs in Czech and Comparable Phenomena in French and Italian." In The Syntax of Pronominal Clitics, edited by Hagit Borer, 123-145. Orlando, FL: Academic Press.

Vainikka, Anne, and Joan Maling. 1996. "Is Partitive Case Inherent or Structural?" In Partitives: Studies in the Syntax and Semantics of Partitive and Related Constructions, edited by Jacob Hoeksema, 179-208. Berlin: De Gruyter.

Vermandere, Dieter. 2002. "A Unified Analysis of French and Italian en/ne." In Current Issues in Romance Languages: Selected Papers from the 29th Linguistic Symposium on Romance Languages, edited by Teresa Satterfield, Christina Tortora, and Diana Cresti, 359-373. Amsterdam: John Benjamins.

Wilkinson, Karina. 1991. "Plural Pronouns and the Partitive Constraint." In Proceedings of NELS 21, edited by Tim Sherer, 399-413.

Zamparelli, Roberto. 1995. "Layers in the Determiner Phrase." PhD diss., University of Rochester.

Zamparelli, Roberto. 1998. "A Theory of Kinds, Partitives and of/z Possessives." In Possessors, Predicates and Movement in the Determiner Phrase, edited by Artemis Alexiadou and Christopher Wilder, 261-301. Amsterdam: John Benjamins.

Zamparelli, Roberto. 2000. Layers in the Determiner Phrase. New York, NY: Garland. 